\title{
Vegetation analysis of the Taormina Region in Sicily: a plant landscape characterized by geomorphology variability and both ancient and recent anthropogenic influences
}

\author{
Saverio Sciandrello, Sonia D’Agostino and Pietro Minissale (*)
}

\begin{abstract}
Sciandrello, S., D'Agostino, S. \& Minissale, P. Vegetation analysis of the Taormina Region in Sicily: a plant landscape characterized by geomorphology variability and both ancient and recent anthropogenic influences. Lazaroa 34: 151-190 (2013).

The vegetation composition and landscape analysis of the Taormina region (Messina, Sicily) in relation to anthropogenic influences was investigated. A total of 183 phytosociological relevés were performed in the period 2009-2012. Despite strong human influences, the study area is characterized by the occurrence of several plant-communities, mainly represented by woods and shrubs vegetation (Quercetea ilicis), riparian woods and shrubs (Salici purpureae-Populetea nigrae, RhamnoPrunetea), dry grasslands (Lygeo-Stipetea), hygrophilous communities (Molinio-Arrhenatheretea, Phragmito-Magnocaricetea and Isoëto-Nanojuncetea), rupicolous communities (Asplenietea trichomanis, Parietarietea judaicae), rocky coast communities (Crithmo-Limonietea), pasture coenosis (Poetea bulbosae), spring-flowering meadows (Tuberarietea guttatae and Stipo-Trachynietea distachyae) and nitrophilous communities (Onopordetea acanthii). The vegetation analysis allowed the identification of 34 vegetation types, with 8 new associations and 4 new sub-associations, and also allowed the reconstruction of the vegetation series and landscape units (geosynphytosociology). The synphytosociological analysis of the plant communities allowed the identification of the main vegetation series: climatophilous acidophilous series of metamorphic substrates (Erico arboreae-Querco virgilianae sigmetum); climatophilous basophilous series of sedimentary substrates (OleoQuerco virgilianae sigmetum); edaphomesophilous series of the cliffs (Bupleuro fruticosi-Querco ilicis sigmetum); edaphoxerophilous series of the semirupestrian maquis (Euphorbieto dendroidis permasigmetum); edafo-hygrophylous geoseries of the riparian wood (Platano-Salico gussonei geosigmetum); and chasmophilous permaseries of the cliffs (Erucastro virgati permasigmetum, Limonio ionici permasigmetum). Overall, this territory should be considered an area of remarkable geobotanical significance, which still shows interesting vestiges of natural vegetations deserving of preservation.
\end{abstract}

Keywords: vegetation, synphytosociology, Peloritani Mountains, landscape, conservation, Sicily.

Resumen: Sciandrello, S., D’Agostino, S. \& Minissale, P. Análisis de la vegetación de Taormina (Sicilia): un paisaje vegetal de gran variabilidad geomorfológica e influencias antropogénicas antiguas y recientes. Lazaroa 34: 151-190 (2013).

En este trabajo se ha estudiado la vegetación y el paisaje actual de la región de Taormina (Mesina, Sicilia), y su relación con influencias antropogénicas. Un total de 183 inventarios fitosociológicos se realizaron en el período 2009-2012. A pesar de la fuerte influencia del hombre, el área de estudio se caracteriza por la presencia de varias comunidades, principalmente representadas por bosques y matorrales (Quercetea ilicis), bosques ribereños y matorrales espinosos (Salici purpureaePopuletea nigrae, Rhamno-Prunetea), prados secos (Lygeo-Stipetea), comunidades higrófilas (Molinion-Arrhenatheretea, Phragmito-Magnocaricetea y Isoëto-Nanojuncetea), comunidades rupícolas (Asplenietea trichomanis, Parietarietea judaicae), comunidades costeras (Crithmo-Limonietea), pastos (Poetea bulbosae), prados (Tuberarietea guttatae, StipoTrachynietea distachyae) y comunidades nitrófilas (Onopordetea acanthii). El análisis de la vegetación ha permitido la identificación de 34 tipos de vegetación, 8 asociaciones y 4 subasociaciones nueves, así como la reconstrucción de las series de vegetación y de las unidades de paisaje (geo-sinfitosociología). El análisis sinfitosociológico de las comunidades vegetales ha permitido la identificación de las series de vegetación principales: serie climatófila acidófila sobre sustratos metamórficos de Quercus virgiliana (Erico arboreae-Querco virgilianae sigmetum); serie climatófila basófila sobre sustratos sedimentarios de Quercus virgiliana (Oleo-Querco virgilianae sigmetum); serie edafo-mesófila en barrancos de la alsina (Bupleuro fruticosae-Querco ilicis sigmetum); serie edafo-xerófila de matorrales semi-rupestres (Euphorbieto den-

\footnotetext{
* Department of Biological. Geological and Environmental Sciences. University of Catania. Via A. Longo 19. I-95125 Catania, Italy. E-mail: sciandrello.s@ hotmail.it
} 
droidis permasigmetum); geoserie edafo-higrófila de saucedas (Platano-Salico gussonei geosigmetum), y permaseries casmofítica de acantilados (Erucastro virgati permasigmetum, Limonio ionici permasigmetum). En general, este territorio debe ser considerado como un área de notable importancia botánica, que aún muestra vestigios interesantes de vegetación natural que merecería estar incluida en alguna figura de conservación.

Palabras clave: vegetación, sinfitosociología, Peloritani, paisaje, conservación, Sicilia.

\section{INTRODUCTION}

For centuries, the Mediterranean area has been subjected to countless human actions which have severely altered the plant landscape. Sicily, the largest island in the Mediterranean basin, has been exploited for millennia by different peoples who succeeded in radically transforming the wooded landscape of the island. The most important transformations, determined by timber harvesting, agricultural expansion and development of grazing, occurred with the Greek colonization as demonstrated by pollen data (NoTI \& al., 2010; SADORI \& NARCISI, 2001). The first Greek colony was in the fifth century (B.C.) at Naxos, on the Ionian coast below the actual site of Taormina.

Today, the area of Taormina, despite uninterrupted and prolonged human disturbance, is still one of the most interesting Peloritani area with regards to biodiversity (BRULLO \& al., 1995; SCIANDRELLO \& al., 2013). In fact, it still preserves exclusive plant communities, characterized by rare and peculiar species, both from an ecological and phytogeographical viewpoint.

The naturalistic high value of the area allowed it to be included in the network of Sites of Community Importance (SCI) according to the Habitats Directive (cod. ITA 030004 "Bacino del Torrente Letojanni", cod. ITA 030031 "Isola Bella, Capo Taormina and Capo St. Andrea, cod. ITA 030003 "Rupi di Taormina and Monte Veneretta"). In addition, the area has been identified as a strategic site for the conservation of plant species of natural interest (IPA - Monti Peloritani and Rupi di Taormina) (BLASI \& al., 2011). The Taormina region also has remarkable peculiarities in terms of geological features (LENTINI \& al., 1984; 2000), contributing to the diversification of the plant landscape.

For this area, detailed investigations on the vegetation are lacking with the exception of specific contributions to the Asplenietea trichomanis (BRULlo \& al., 2004), Parietarietea judaicae (BRULlo \& GuARINO, 2002) and Aristido caerulescentisHyparrhenion hirtae (BRULLO \& al., 1997). On the other hand, detailed studies on the flora and vegetation have been carried out only for the nearby site of community interest "Capo Taormina, Isola Bella and Capo S. Andrea" characterized by coastal vegetation (MinISSALE \& al., 2005).

The aim of this research is to provide a framework of the vegetation, designed to reconstruct the serial relationships between different plant communities related not only to the anthropogenic influence but also to the different geological substrates. A knowledgeable framework will also give useful information for correct management and planning of the territory.

\section{MATERIALS AND METHODS}

\section{STUDY AREA}

The study area is located in the southern part of the Peloritani Mountains (E Sicily) and occupies an area of about 6,000 hectares, covering the territories of Taormina, Castelmola, Mongiuffi Melia, Roccafiorita, Letojanni, Gallodoro, Forza D'Agrò and their surroundings (Figure 1). The area is characterized by the presence of relatively low altitude hills, represented by Monte Tauro (245 m), Monte Petraro (475 m), Castelmola (496 m), Roccella (602 m), Monte Ziretto (381 m), Costa Ogliastro (466 m), Monte Veneretta (884 m), Monte Lapa $(771 \mathrm{~m})$, Monte Castelluccio (501m), Monte Pernice (712 m), and Monte Galfa (1000 m), charactized by cliffs and narrow river valleys ( $T$. Mortelletto and T. S. Antonio). From a geological viewpoint, the study area belongs mainly to the Longi-Taormina Unit and Capo S. Andrea Unit (LENTINI \& al., 2000). The lower subunit is formed 


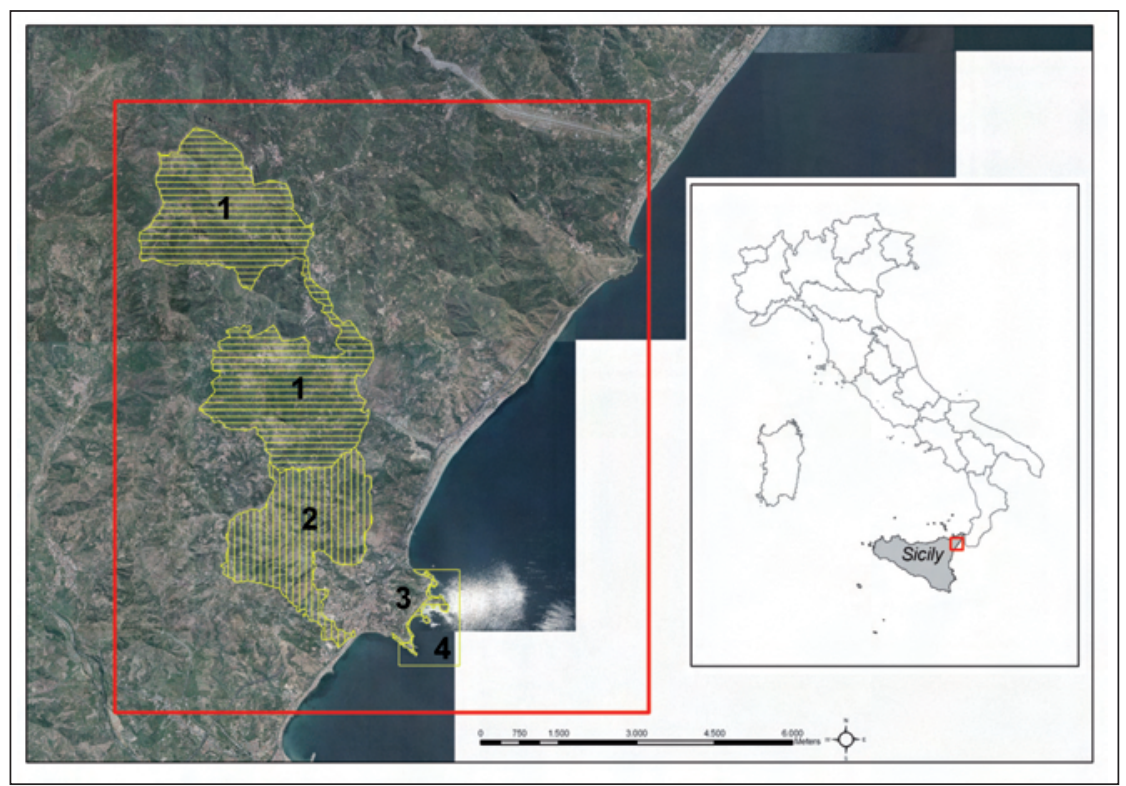

Figure 1. - Study area. Natura 2000 sites: 1. Bacino del Torrente Letojanni (ITA030004), 2. Rupi di Taormina Monte Veneretta (ITA030003), 3. Isola Bella, Capo Taormina Capo St. Andrea (ITA030031), 4. Fondali di Taormina - Isola Bella (ITA030040).

by an epimetamorphic basement, capped by a Mesozoic-Cenozoic sedimentary cover formed (bottom to top) from continental redbeds, evolving upwards to platform carbonates (CATALANO, 2010).

On the basis of climatic data from several weather stations in Taormina and its surroundings, (http://www.sias.regione.sicilia.it/SIT/Temperature) there is a decreasing gradient of the mean annual temperature corresponding to increasing altitude which correlates as follows: Taormina Isola Bella (18-19º, M.Tauro-M. Castelluccio (17-18 ${ }^{\circ}$, Castelmola-M.Petraro-M.Castelluccio $\left(16-17^{\circ}\right)$, Roccella-Monte Ziretto-Costa OgliastriM.Lapa-M.Pernice (15-16 ${ }^{\circ}$, M.Lapa-M.Pernice $\left(14-15^{\circ}\right)$, and M.Veneretta-M.Galfa (13-14 ${ }^{\circ}$.

Annual precipitation at the sites ranges from $600 \mathrm{~mm}$ (along the coast) to about $1000 \mathrm{~mm}$ (inland area).

According to the bioclimatic classification proposed by Rivas-MartíneZ (1983, 1993) and RIVAS-MARTíNEZ \& al. (2004), the area under study is referred to the Mediterranean pluviseasonal oceanic bioclimate, with thermotypes ranging from the low thermomediterranean to the supramediterranean, and ombrotypes from the se- miarid to lower humid (BRULlo \& al., 1996; SCELSI \& SPAMPINATO, 1998).

\section{VEGETATION ANALYSIS}

The vegetation analysis was carried out following the phytosociological method (BRAUNBLANQUET, 1964) taking into account the most recent acquisitions related to synphytosociology and geosynphytosociology (BIONDI, 2011; RIVASMARTínez, 2005). A total of 183 phytosociological relevés were performed in the period 2009-2012. Subsequently, the surveys related to woody-scrub vegetation, annual grassland and hygrophilous vegetation were subjected to multivariate analysis using Syntax 2000 software (PoDANI, 2001). Original Braun-Blanquet sampling scales were transformed into the ordinal scale according to VAN DER MAAREL (1979). A hierarchic classification method (UPGMA) was performed. For the nomenclatural and taxonomical aspect, Giardina \& al. (2007), RAimondo \& SPADARO (2009) were followed, while for the syntaxa classification RIVAS-MARTÍNEZ \& al. (2001) and BRULLO \& al. (2002) were used. 


\section{RESULTS AND DISCUSSION}

The phytosociological survey identified 34 well differentiated vegetation types in terms of floristic, physiognomic-structural and ecological features, including 8 new associations and 4 new sub-associations.

Cluster analysis of the wood-shrub vegetation allowed to distinguish six main plant communities with specific differential species, three communites of annual dry grassland and four types of hygrophilous vegetation. They are listed in the syntaxonomical scheme (Appendix 1):

\section{WOOD AND SHURB VEGETATION}

In the study area, the woody vegetation of the Quercetea ilicis class is quite diversified in relation to the different geological substrates and especially in relation to the degradation factors which led to an almost complete disappearance of the forests and to a progressive establishment of many secondary communities. Cluster analysis allowed various phytocoenoses to be highlighted and distinguished, each one being an indicator of different ecological conditions (Figure 2).

On the slopes of the hills, there are fragments of woody vegetation dominated by Quercus vir- giliana (Figure 5). This community is often poorly structured due to intense human disturbance (mainly bushfires). In other cases, they are in a re-expansion phase on areas once cultivated and therefore, the floristic composition has not yet stabilized and lacks many forest species. The tree layer is formed by Quercus virgiliana, Fraxinus ornus while the shrub is represented by Rhamnus alaternus, Cytisus villosus, Calicotome infesta and sporadically by Erica arborea. This community generally grows in more or less deep soils on metamorphic substrates and, due the presence of Erica arborea and other acidophilous species, it belongs to Erico-Quercetum virgilianae (Table 1; Figure 2, cluster B). This association develops in the bioclimatic range from thermomediterranean to mesomediterranean between the upper dry and the lower sub-humid ombrotype (BRULLO \& MARCENÒ, 1985; BRULlo \& al., 1996; 2008). In the Peloritani Mountains this association, despite its high degree of fragmentation, is very widespread. On deep soils derived from calcareous substrate Erico-Quercetum virgilianae has probably been replaced by Oleo-Quercetum virgilianae, a basophilous-neutrophilous vegetation quite widespread in Sicily (BRULLO \& al., 2008).

On the limestone cliffs, in particular the north/north-east exposure of Mount Veneretta, M.

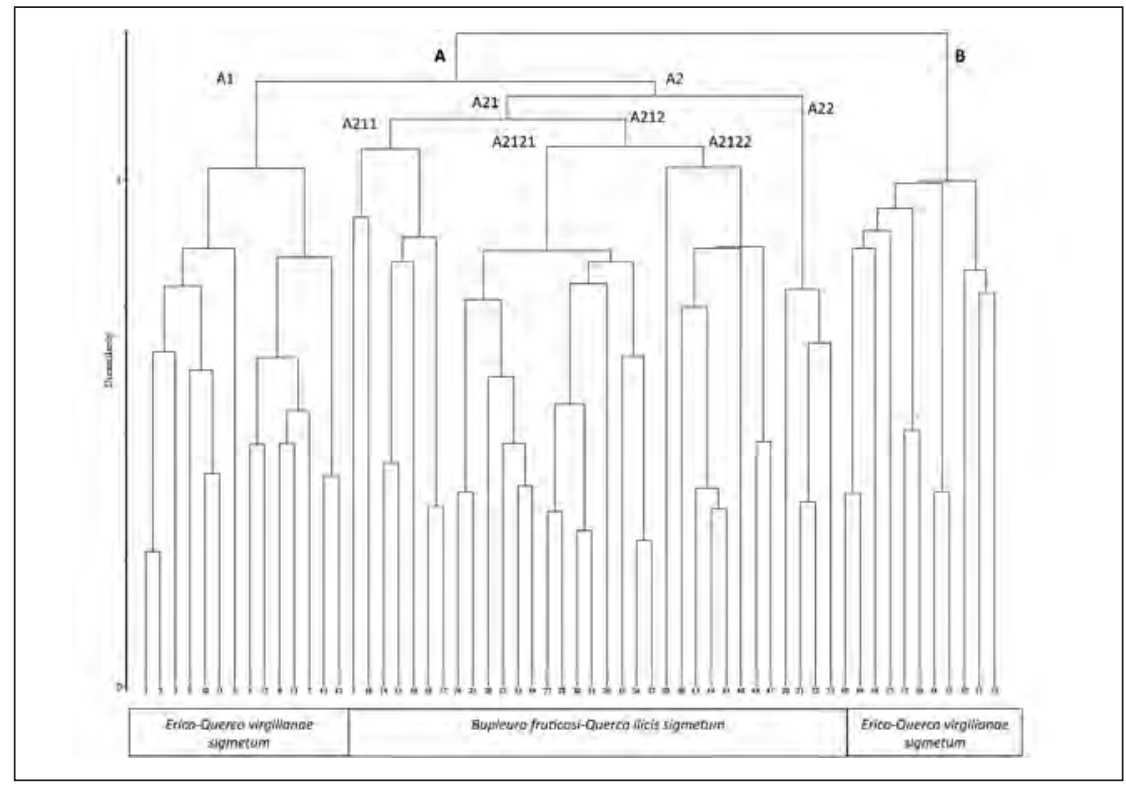

Figure 2. - Cluster analysis of the wood and shrub vegetation. 


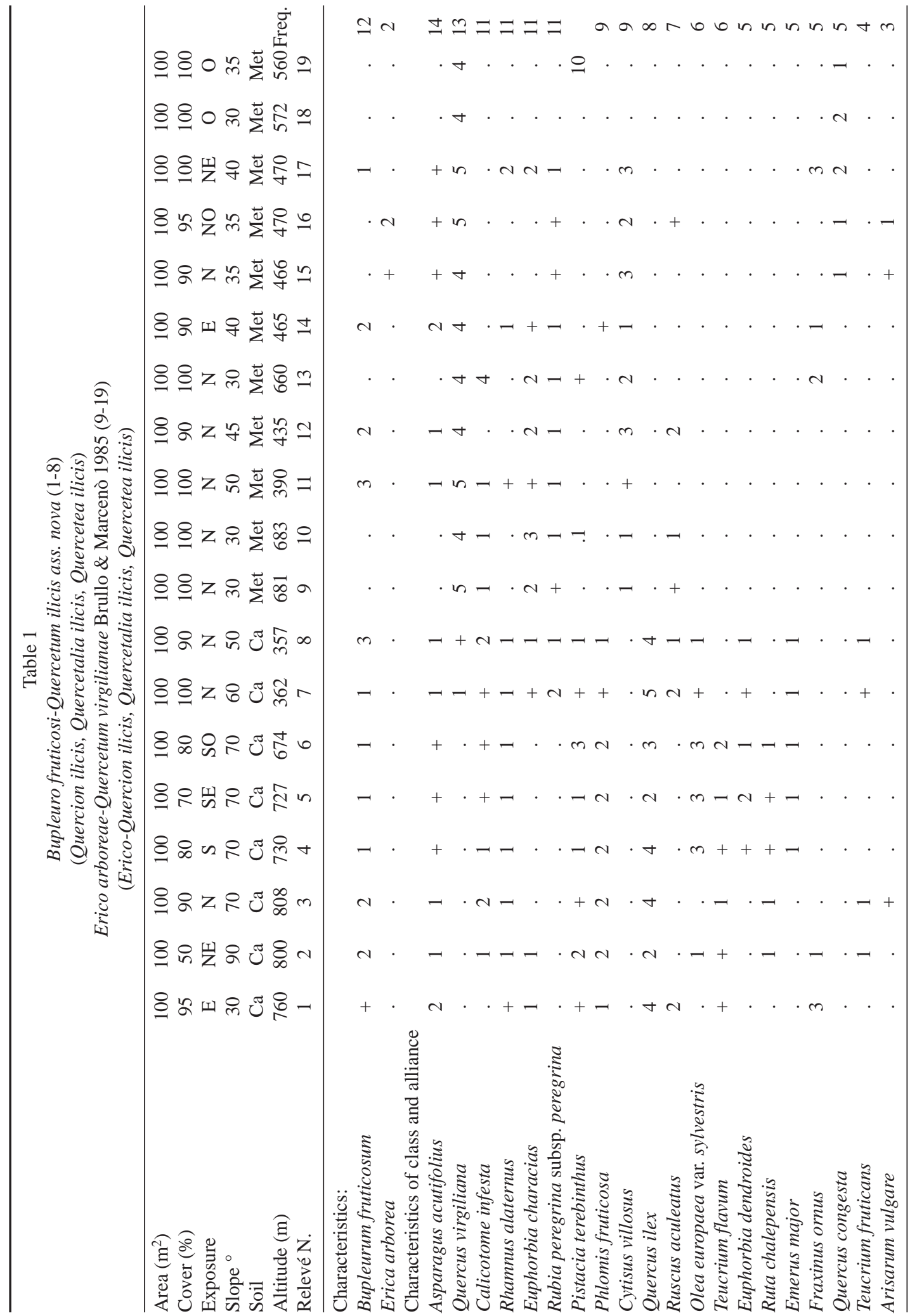




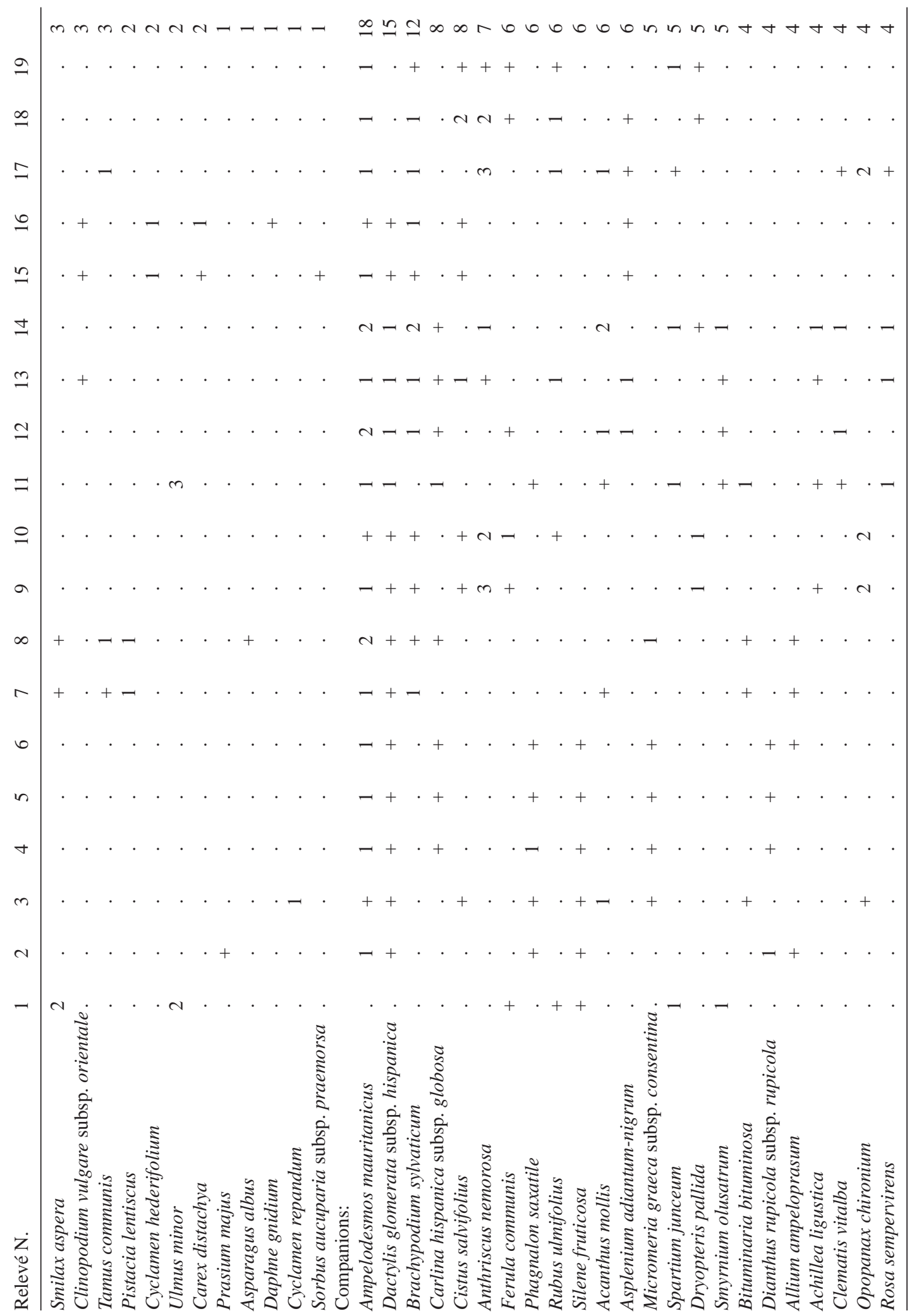




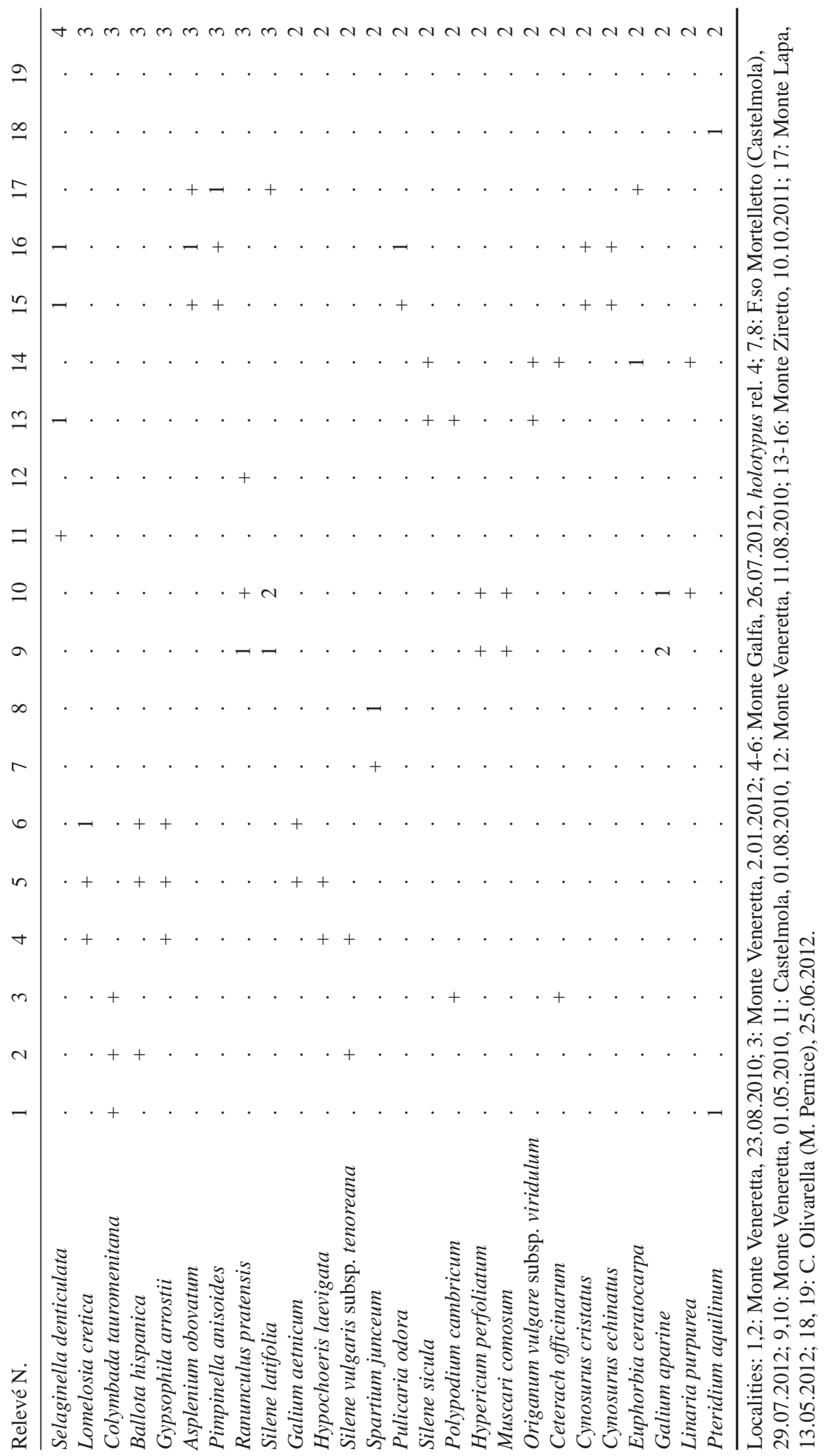


Lapa and M. Galfa, a peculiar rupestrian treeshrub vegetation grows. These patches are dominated by Quercus ilex (Figure 2, cluster A2122). From a structural viewpoint, the vegetation is characterized by the presence of several species of Quercion ilicis and Quercetea ilicis, such as Quercus ilex, Fraxinus ornus, Bupleurum fruticosum, Phlomis fruticosa, Rhamnus alaternus, Pistacia terebinthus, etc. This vegetation resembles Rhamno alaterni-Quercetum ilicis, a climatophilous plant community linked to hilly areas in the mesomediterranean bioclimatic belt and influenced by coastal breezes in north-west Sicily (BRULLO \& al., 2008; GianguZZi \& LA MANTiA, 2008).

The community studied in this paper differs from the above mentioned Rhamno alaterniQuercetum ilicis by the presence and abundance of Bupleurum fruticosum, a mesophilous species with a west-Mediterranean distribution. Moreover, this shrub is not common in Sicily (GIARDINA $\& a l ., 2007)$ and is here proposed as Bupleuro fruticosi-Quercetum ilicis (Table 1, holosyntypus: rel. 4). This vegetation represents the most mature step of an edaphic series linked to rocky slopes, in contact with the semi-rupicolous vegetation of the Euphorbietum dendroidis and the chasmophilous vegetation of the Dianthion rupicolae.

The vegetation dominated by Euphorbia dendroides is the most thermo-xerophilous shrub community of this area and is localized on rocky, mainly south facing slopes of the cliffs from just above the coastline to 600 metres above sea level (Figure 2, cluster A2121). Several shrub species of the Oleo-Ceratonion alliance characterizes $\mathrm{Eu}$ phorbietum dendroidis (Table 2), such as Calicotome infesta, Teucrium fruticans, Pistacia lentiscus, Smilax aspera, Prasium majus, Olea europaea var. sylvestris, Phlomis fruticosa, etc. This association is widespread in Sicily and is localized in both coastal and inland areas (MINISSALE \& Sciandrello, 2005; Minissale \& al., 2005, 2007, 2011; BRULlo \& al., 2008; GiANGUZZI \& $a l ., 2010)$. This vegetation is in contact with the chasmophilous vegetation of Erucastretum virgati, with which it is sometimes mixed, forming a transition community. Another thermophilous shrub vegetation present along the coast is $\mathrm{Teu}$ crio fruticantis-Rhamnetum alaterni, which grows on calcareous rocks under deep soil (MINISSALE \& al., 2005).

A sparse vegetation, with a high floristic diversity and characterized by the dominance of Calicotome infesta, grows on substrates of metamorphic origin, which are more or less inclined (Figure 2, cluster A1). This vegetation is rich in the sclerophyllous species belonging to Oleo-Ceratonion, such as Euphorbia characias, Olea europaea var. sylvestris, Rhamnus alaternus, Prasium majus, Asparagus albus, etc. The presence of Cistus salvifolius is also ecologically significant because it shows the pyrophilous character of the vegetation. This chamaephyte is therefore indicated as a characteristic species of a new association, here proposed as Cisto salvifolii-Calicotometum infestae (Table 2 , holosyntypus: rel. 4). This is a secondary community derived from the degradation processes of woods belonging to Erico-Quercetum virgilianae, as highlighted by the presence of rare individuals of Erica arborea, Quercus virgiliana and Q. congesta. This new community also occurs on very steep slopes, characterized by metamorphic outcrops where elements of the former woodland still survive, such as Quercus ilex in shrub form and Erica arborea, and other elements of Quercetea ilicis. Cisto salvifolii-Calicotometum infestae is comparable in a dynamic role to Pyro spinosae-Calicotometum infestae corr. hoc loco, as described by GianguzZI \& LA Mantia (2008) for the western sector of Sicily but it normally prefers calcareous substrates.

Between $100 \mathrm{~m}$ and $1000 \mathrm{~m}$ above sea level on greatly eroded dolomitic or limestone outcrops, a secondary rupicolous vegetation, characterized by the dominance of Phlomis fruticosa, has developed (Figure 2, cluster A211). It is a low-shrub vegetation, rich in xerophilous species, such as Teucrium fruticans, Pistacia lentiscus, Ruta chalepensis, Prasium majus, etc. In phytogeographical terms, the presence of Micromeria graeca subsp. consentina, an endemic species of southern Italy and of Sicily is significant and highlights the basiphilous character of the above vegetation. This chamaephyte is therefore proposed as a characteristic of a new association, $\mathrm{Mi}$ cromerio consentinae-Phlomidetum fruticosae (Table 2, holosyntypus rel.17). This association is 


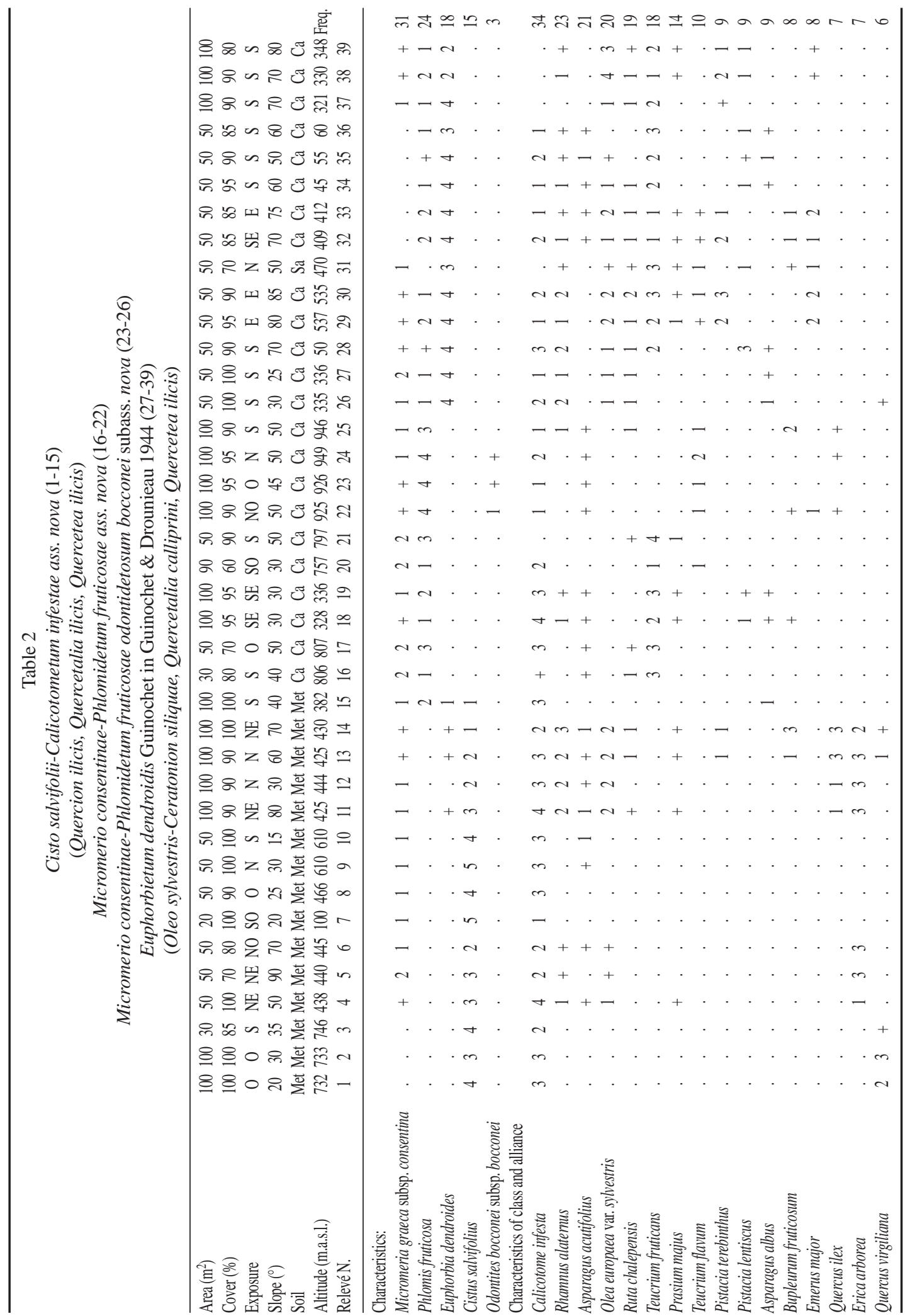




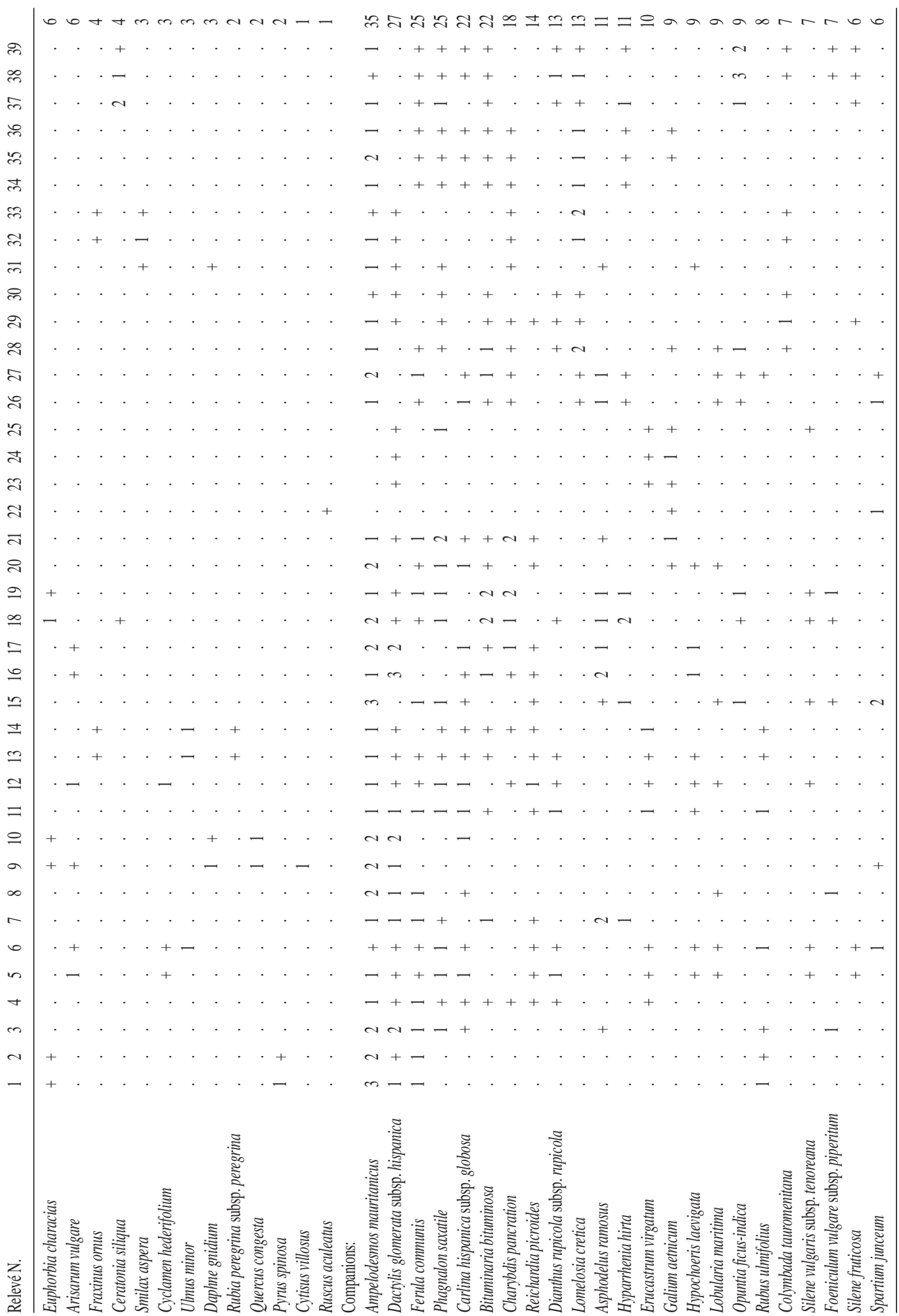




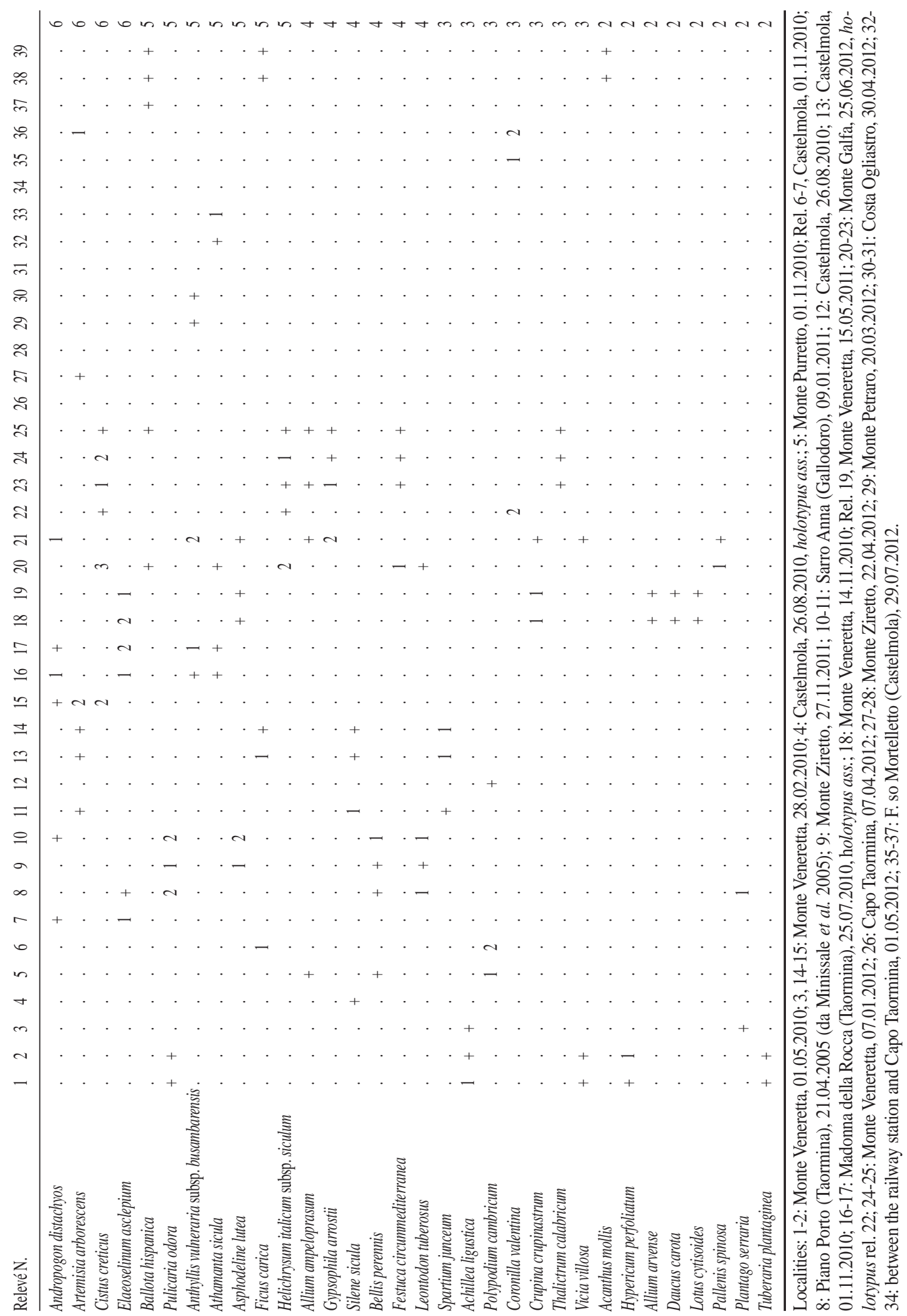


linked to the degradation processes of evergreen oaks woods ascribed to Bupleuro fruticosi-Quercetum ilicis. In Sicily Micromerio consentinaePhlomidetum fruticosae shows some similarities to the Salvio-Phlomidetum fruticosae community, having a south-eastern distribution in Sicily (MINISSALE \& al., 2007).

At higher altitudes, Micromerio consentinaePhlomidetum fruticosae loses most of the thermophilous species (Figure 6), such as Teucrium fruticans whereas the presence of more mesophilous species increases, such as Odontithes bocconei which is endemic to Sicily (Figure 2, cluster A22). This allows a new sub-association to be differentiated and named odontitetosum bocconei (Table 2, holosyntypus: rel. 22). It is localized on the north/northwest facing slopes of Mount Galfa, between 900-1000 m asl, in contact to the chasmophilous vegetation of the Dianthion rupicolae.

\section{PERENNIAL AN ANNUAL DRY GRASSLAND}

The perennial steppic plant communities are fairly widespread in the investigated area. This vegetation, an expression of the degradation of woody vegetation, is quite diversified in relation to ecological factors, such as moisture, frequency of bushfires, nutrients in the soil, etc. The phytosociological analysis allowed different plant communities, mainly ranging in Lygeo-Stipetea class, to be distinguished.

The most widespread plant communities are grasslands dominated by Ampelodesmos mauritanicus and mixed with many hemicriptophytes and chamaephytes, such as Carlina hispanica subsp. globosa, Ferula communis, Elaeoselinum asclepium, Dactylis glomerata subsp. hispanica, Carlina gummifera, Hyparrhenia hirta, Charybdis pancration, Andropogon distachyos (Figure 7). These grasslands are common in Sicily (MINISSALE, 1995) and, despite having similar ecological requirements and dynamic significance they can be differentiated according to the floristic composition which varies in different regions of Sicily. In the studied territory, the vegetation is characterized by the presence of Galium aetnicum and is therefore attributable to Galio-Ampelodes- metum mauritanici (Table 3), an association widespread in the Peloritani Mountains (MinISSALE, 1995). It is a grassland which colonizes mainly siliceous substrates with different degrees of metamorphism. It grows from sea level up to $800 \mathrm{~m}$ and within the bioclimatic thermo-mesomediterranean belt with a subhumid ombrotype. This plant community is closely linked to the degradation of the forests belonging to Erico-Quercetum virgilianae.

Between 400 and $800 \mathrm{~m}$ above sea level on carbonate substrates of Mount Veneretta, M. Galfa and Forza d'Agrò, Galio-Ampelodesmetum mauritanici is replaced by Seselio-Ampelodesmetum mauritanici (Table 3). The latter is located within the bioclimatic thermo-mesomediterranean belt with a sub-humid ombrotype. Also in this case Ampelodesmos mauritanicus is dominant and it is associated with different species of the Lygeo-Stipetea class. A rare Sicilian species Seseli tortuosum subsp. tortuosum, (BRULLO \& al., 2011) characterizes this association. These communities were already known to central Sicily (Minissale, 1995) on limestone or trubi substrata. From a syndynamic viewpoint, these grasslands are linked to the thermophilous oak woods (BRULLO \& al., 2010).

At altitudes from $50 \mathrm{~m}$ up to $500 \mathrm{~m}$, a steppic vegetation dominated by Hyparrhenia hirta and Ferula communis grows on uncultivated and sunny soils frequently subjected to bushfires. From a structural viewpoint, this vegetation is characterized by several perennial plants, such as Asphodelus ramosus, Charybdis pancration, Bituminaria bituminosa, Convolvulus althaeoides, Reichardia picroides, Pallenis spinosa, etc.; so it can be ascribed to Ferulo-Hyparrhenietum hirtae (Table 3). This vegetation was described for the first time by BrUllo \& Siracusa (1996) on the Linosa island; after it was reported by BRULLO \& al. (2010) for several localities of Sicily FeruloHyparrhenietum hirtae represents a recolonization community of abandoned agricultural areas but also a stage in the degradation process of the forest vegetation or maquis.

Growing on steeper, slightly sunny slopes from lower elevations up to $600-700 \mathrm{~m}$, is a community dominated by Arundo collina, ascribed to the 

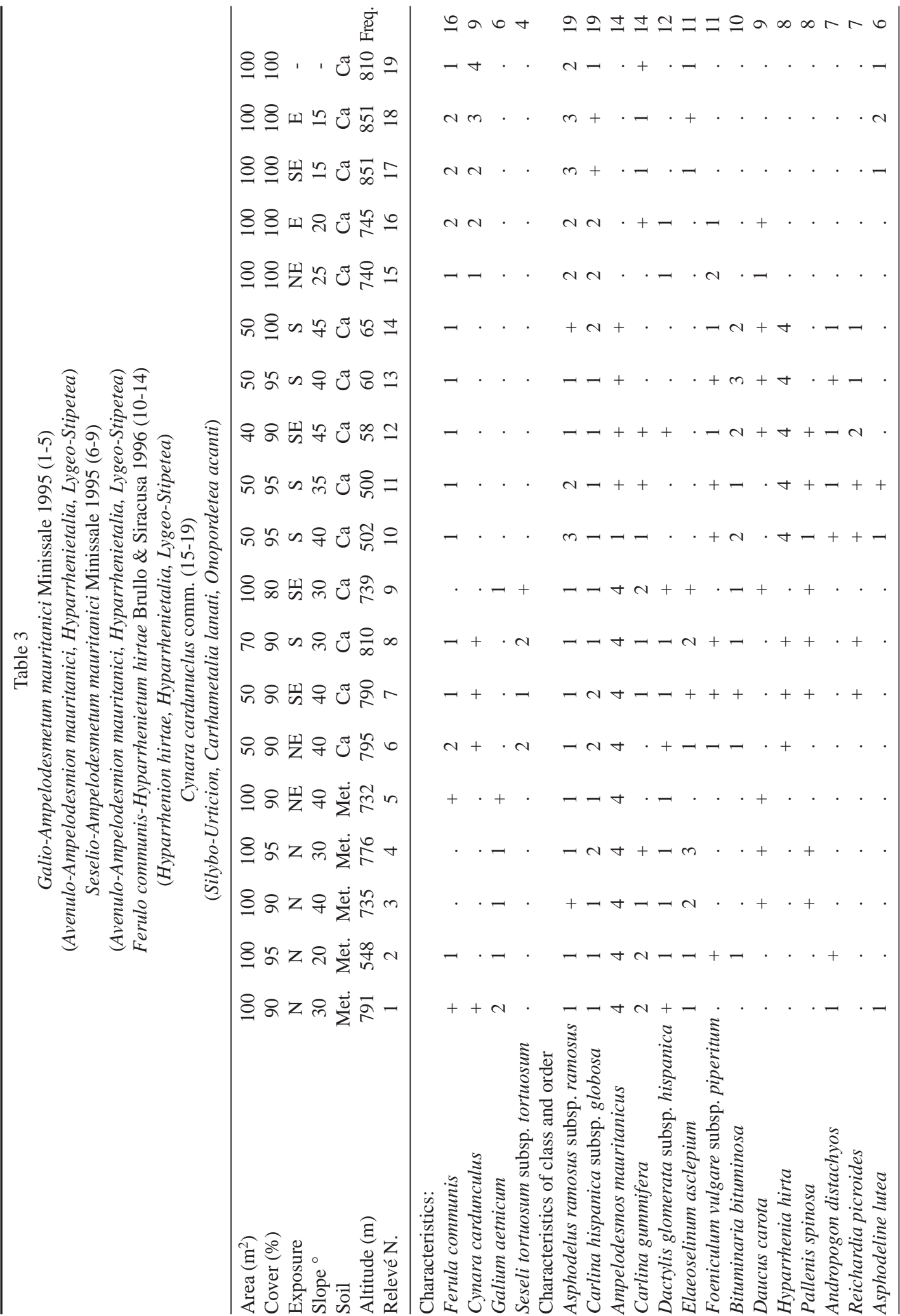


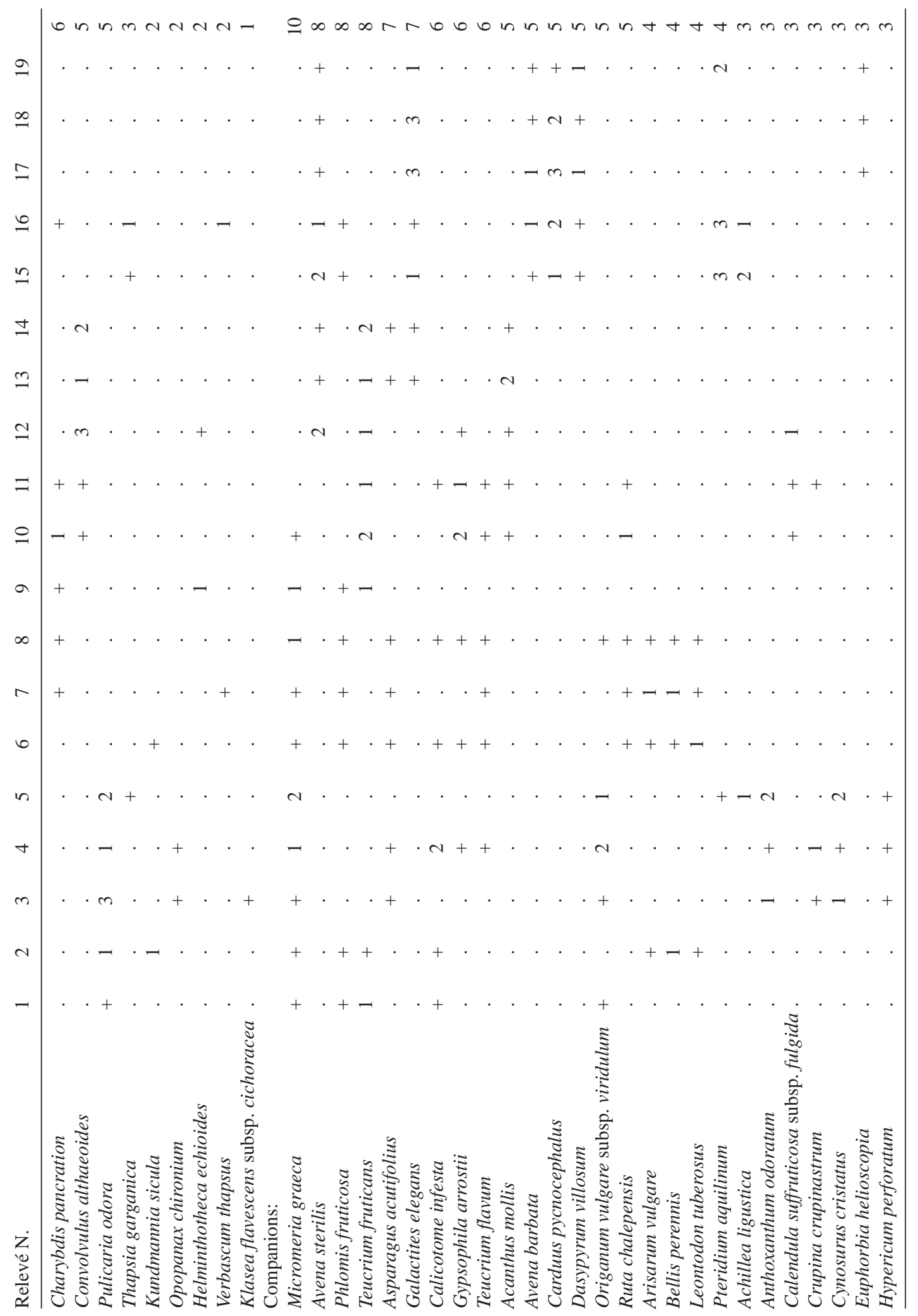




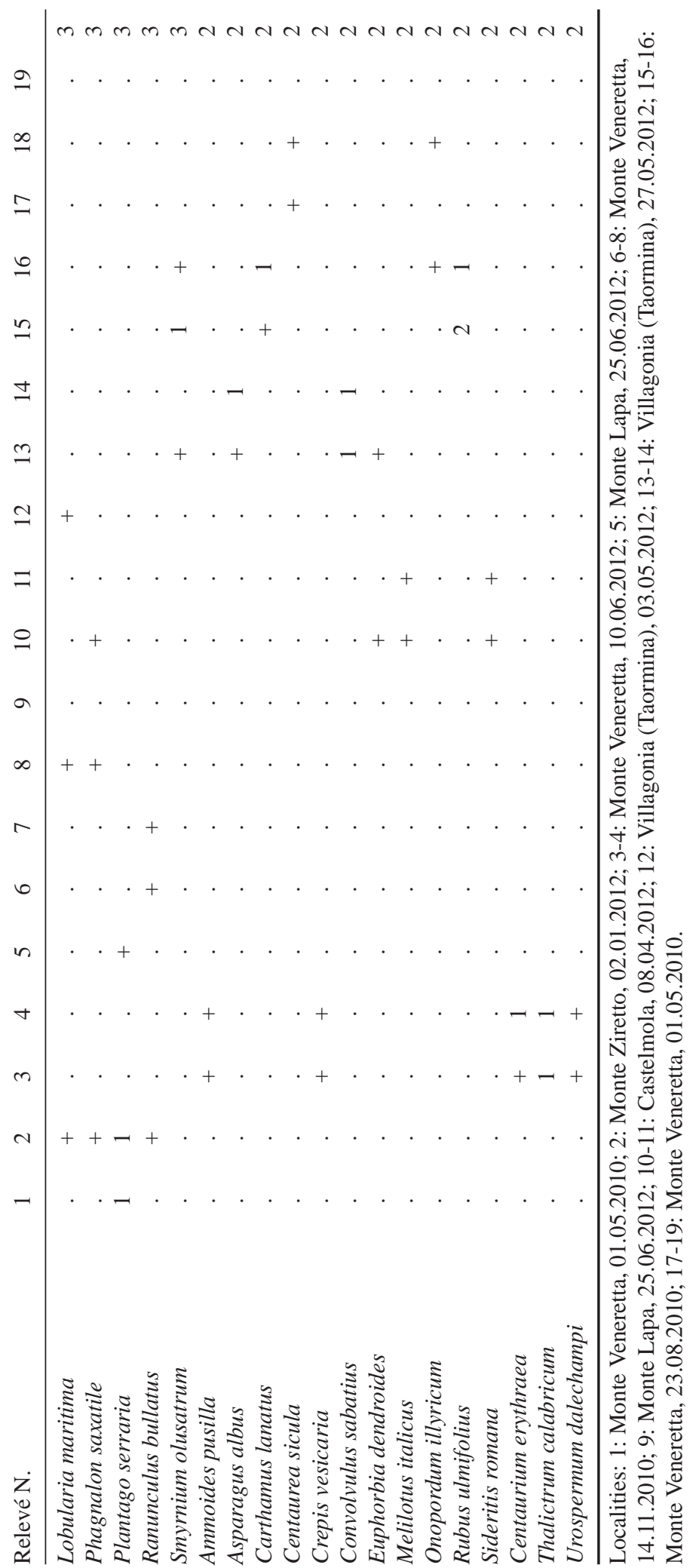


Euphrobio ceratocarpae-Arundinetum collinae association, described by BRULLO \& al. (2010) for various territories in Sicily.

Flat or moderately sloping areas, subjected to periodic bushfires and overgrazing, are often covered by plant communities dominated by Cynara cardunculus. This species is associated with other spiny Asteraceae such as Carduus pycnocephalus, Galactites elegans, Carlina gummifera, Carlina hispanica subsp. globosa, and many synanthropic species, such as Asphodelus ramosus, Dasypyrum villosum, Avena barbata, Avena sterilis, Asphodeline lutea, Euphorbia helioscopia, etc. All of the above species are favoured by grazing and soils rich in nitrates. This plant community occupies much localized areas in the study area (Cynara cardunculus comm., Table 3).

Annual dry grassland, with an autumn-spring cycle characterized by several therophytes; small ephemeral bulbous plants and little hemicryptophythes, are favoured by the Mediterranean climate with its prolonged summer droughts and by human activity such as grazing and controlled bushfires. Natural undisturbed development of the vegetation would lead to maquis and forest growth except on very shallow soils in rocky environments but burning and grazing prevents this and moreover, creates open spaces which are quickly colonized by annuals. In the study area, the vegetation is diversified in relation to the different lithological substrates and the type of anthropogenic influence. Although there are some species in common among different plant communities with a wide ecological niche, every plant community is characterized by large contingents of indicator species in specific ecological conditions. Consequently, they can be attributed to different phytosociological class, such as Poetea bulbosae, Tuberarietea guttatae and Stipo-Trachynetea distachyae. The cluster analysis accurately highlights this diversity and allows three main groups to be identified (Figure $3)$.

The first cluster incluided herbaceous vegetation dominated by Poa bulbosa, an anthropogenic grassland consisting of low perennial herbs, therophytes and various geophytes (Figure 3, cluster B2). It was observed on the summit of Mount Veneretta, which is characterized by shallow soils derived from limestone substrata and subjected to intensive grazing (RIBEIRo \& al., 2012). This vegetation, while dormant during the summer, at the beginning of the autumn season with the arrival of the first rains grows quite fast and remains green throughout the winter. In spring, a large

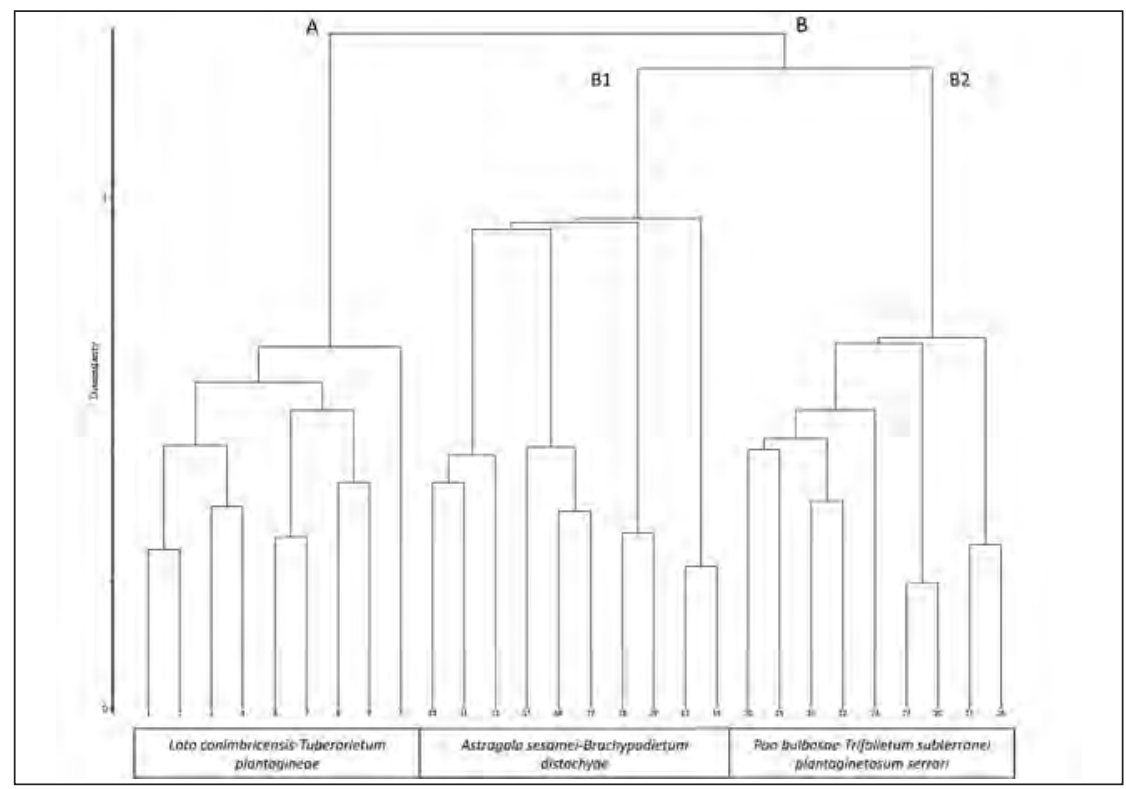

Figure 3. - Cluster analysis of the annual dry grassland. 
number of flowering therophytes grows. These grasslands are rich in many species of the Poetea bulbosae class, such as Trifolium subterraneum, T. suffocatum, Moraea sisyrinchium, Scorzonera villosa subsp. columnae, Trifolium nigrescens, Parentucellia latifolia, Ranunculus paludosus, Romulea columnae, etc. For the floristic composition and ecology of this community, it belongs to the Trifolio subterranei-Periballion, an alliance known in the western Mediterranean basin, such as Spain, Portugal and northern Morocco (GALÁN DE MERA \& al., 2000; CANO \& al., 2007; SILVA \& al., 2009; RiBEIRO \& al., 2012), where it is reported on siliceous substrates.

The association was also reported for Sardinia (LADERO \& al., 1992) but was later classified as Trifolio nigrescentis-Poetum bulbosae (FARRIS \& al., 2007). In this community, the presence of Plantago serraria is significant and is here proposed as a characteristic species of the subassociation Poo bulbosae-Trifolietum subterranei plantaginetosum serrariae (Table 4, holosyntypus: rel. 20). From a bioclimatic viewpoint, this community grows in the thermo-mesomediterranean belts with subhumid ombrotype.

The second group includes a community rich in therophytes, which grows among the gaps of the grasslands referred to as Galio-Ampelodesmetum mauritanici, on acid soils of metamorphic origin (Figure 3, cluster A). This vegetation is characterized by the presence of several species of the Tuberarietea guttatae class, such as Tuberaria plantaginea, Ornithopus compressus, Aira cupaniana, Centaurium maritimum, Lotus angustissimus, Plantago bellardi, Linaria pelisseriana, Trifolium glomeratum, Filago gallica, Petrorhagia prolifera, Tolpis umbellata, etc. The presence of Lotus conimbricensis, a species of great ecological and phytogeographical significance, allows a new association Loto conimbricensis-Tuberarietum plantagineae to be here proposed (Table 4, holosyntypus: rel. 4). From a syntaxonomical viewpoint, this vegetation is related to Linario cirrhosae-Helianthemetum guttati $\mathrm{O}$. Bolos, Molinier \& P. Montserrat 1970, described for the Iberian Peninsula (RIVAS-MARTínEZ \& al., 2002; 2001; PÉREZ PrIETO \& Font, 2005; Bolos, 1996) and Trifolio bocconei-Tuberarietum gutta- tae, described for south-eastern Sicily (BRULLO \& al., 1998) but it is rather different in species composition.

The last group separates a community characterized by several species of Trachynietea distachyae (Figure 3, cluster B1). It grows in the gaps of the grasslands referred to Seselio-Ampelodesmetum mauritanici, on calcareous substrates covered by a thin soil. The more common species are Hippocrepis biflora, Onobrychis aequidentata, Trachynia distachya, Medicago minima var. recta, Hypochaeris achyrophorus, Trifolium stellatum, Lotus edulis, Euphorbia exigua, Ononis reclinata, Linum tryginum, Crupina crupinastrum, Anisantha fasciculata, etc. The peculiar floristic composition makes it possible to identify a new association here proposed as Astragalo sesamaei-Medicaginetum rectae (Table 4, holosyntypus: rel. 10). This vegetation shows some floristic and ecologic similarity to the Onobrychido aequidentatae-Stipetum capensis, an association described by BIONDI \& GUERRA (2008) for Apulia. The arid grassland of Apulia is characterized by the dominance of Stipa capensis, while for Astragalo sesamaei-Medicaginetum rectae, a greater regularity among the most important species in terms of abundance is found.

\section{Cliff vegetation}

On the limestone cliffs of the Taormina region, the plant communities are characterized by several chasmophilous species of considerable phytogeographical interest (Figure 8): they belong to the Asplenietea trichomanis class, such as Erucastrum virgatum, Dianthus rupicola subsp. rupicola, Antirrhinum siculum, Silene fruticosa, Dianthus siculus, Anthyllis vulneraria subsp. busambarensis, Brassica incana, Brassica raimondoi, Lomelosia cretica, Athamanta sicula, Hypochaeris laevigata, Ballota hispanica, etc. (SCIANDRELlo \& al., 2013). Of great significance in these communities is the presence of Colymbada tauromenitana $(=$ Centaurea tauromenitana), a paleoendemic species exclusive to the Taormina region (SCIANDRELLO \& D'Agostino, 2013), and which characterizes Erucastretum virgati subass. centauretosum taurome- 


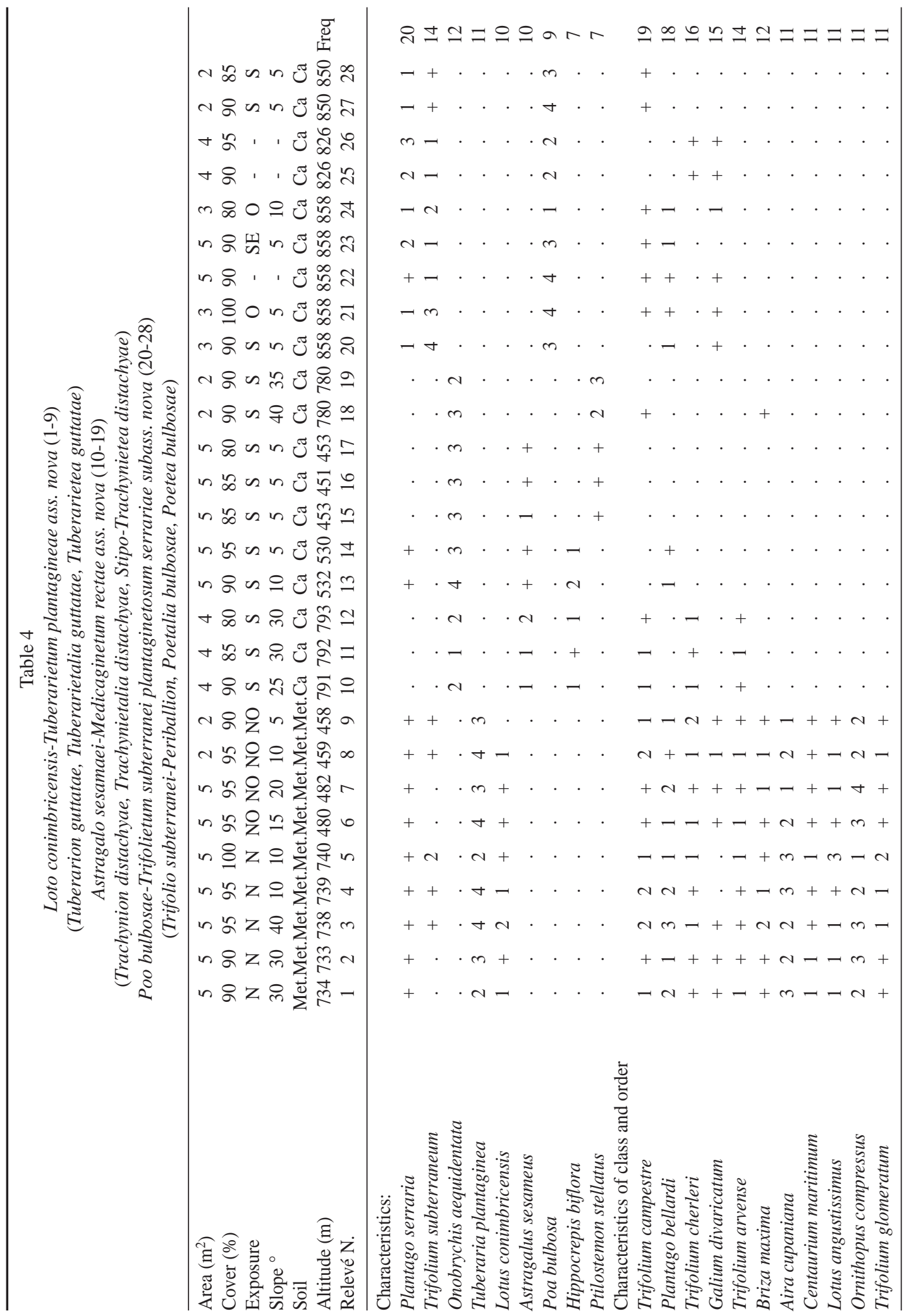




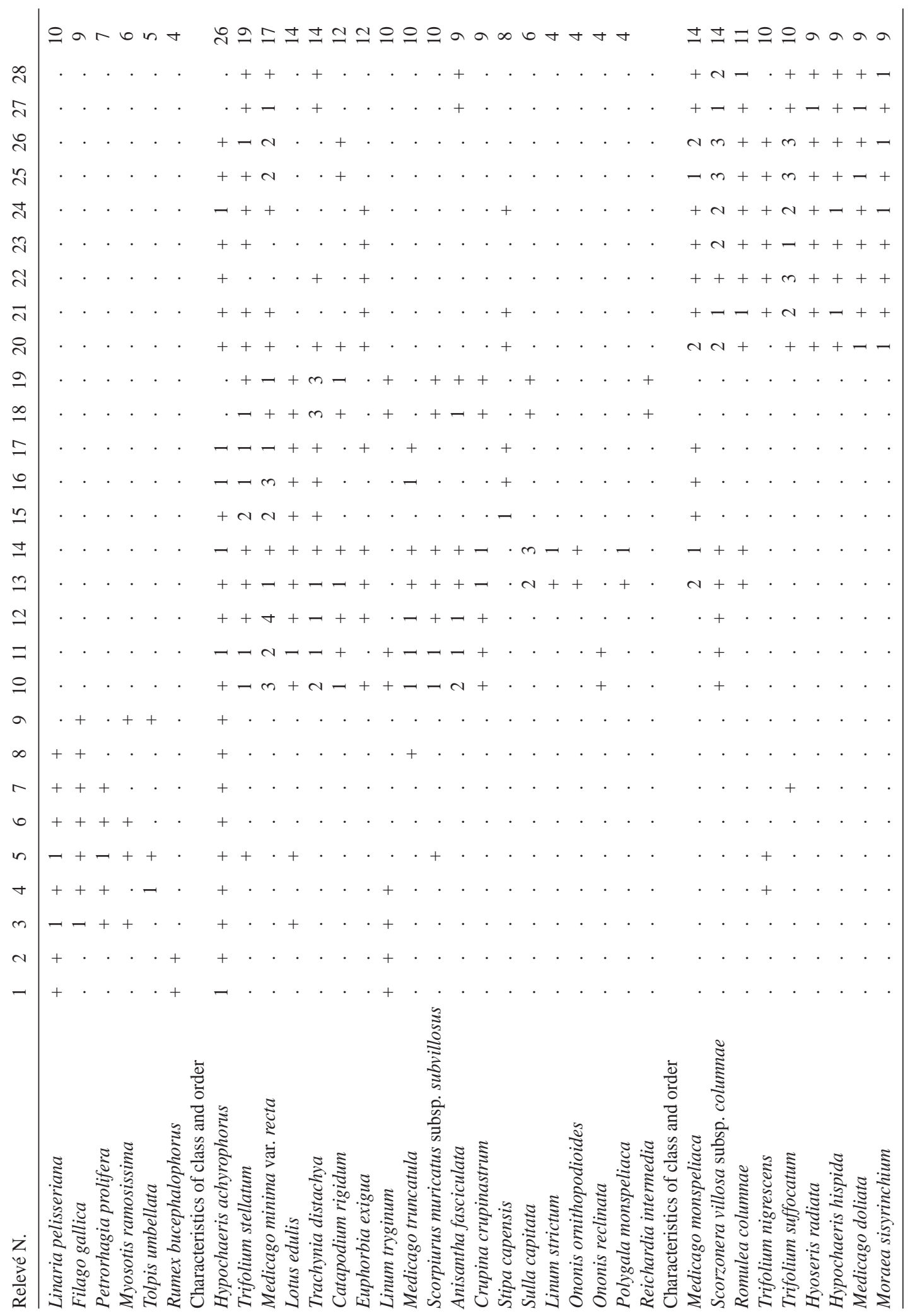




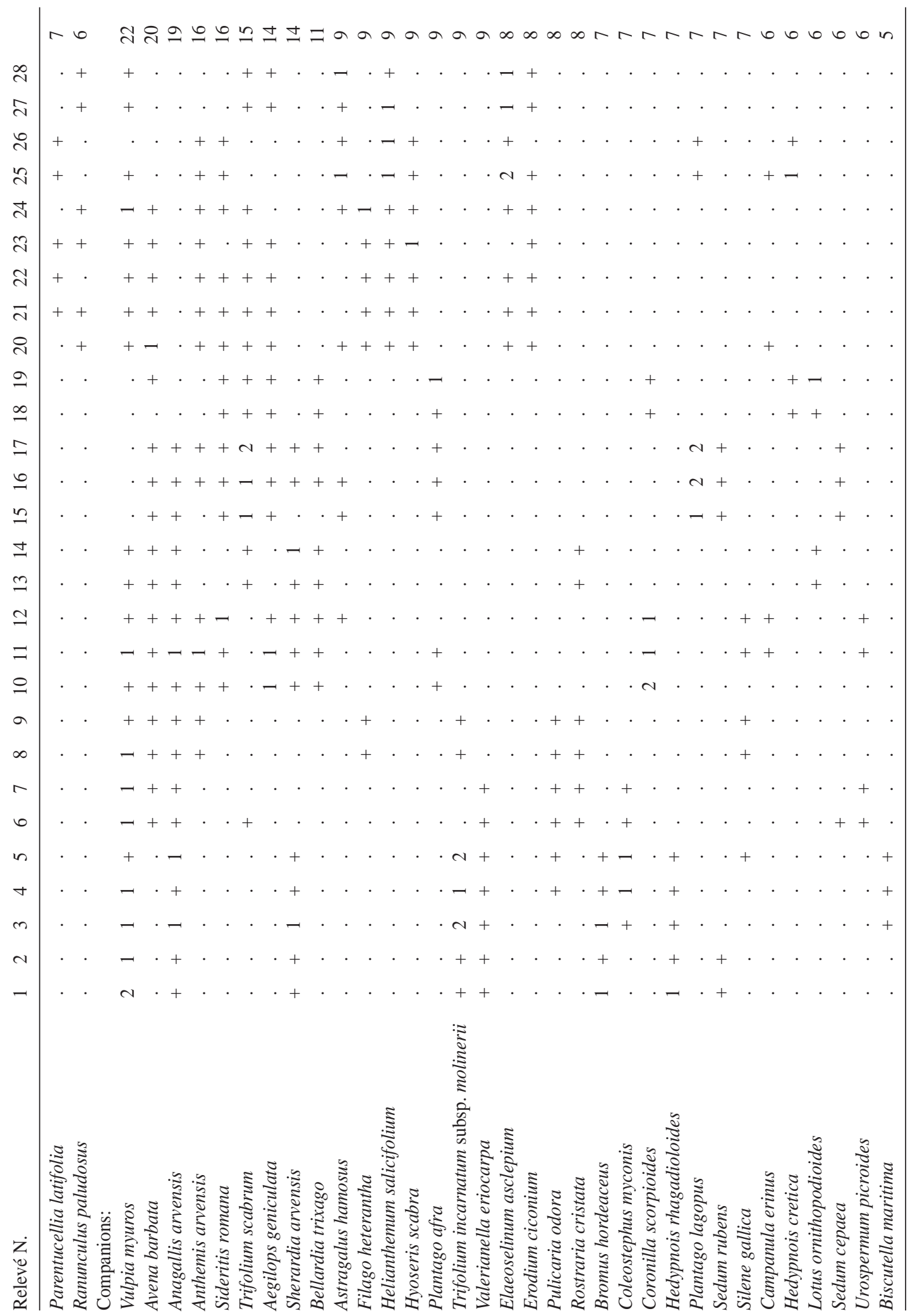




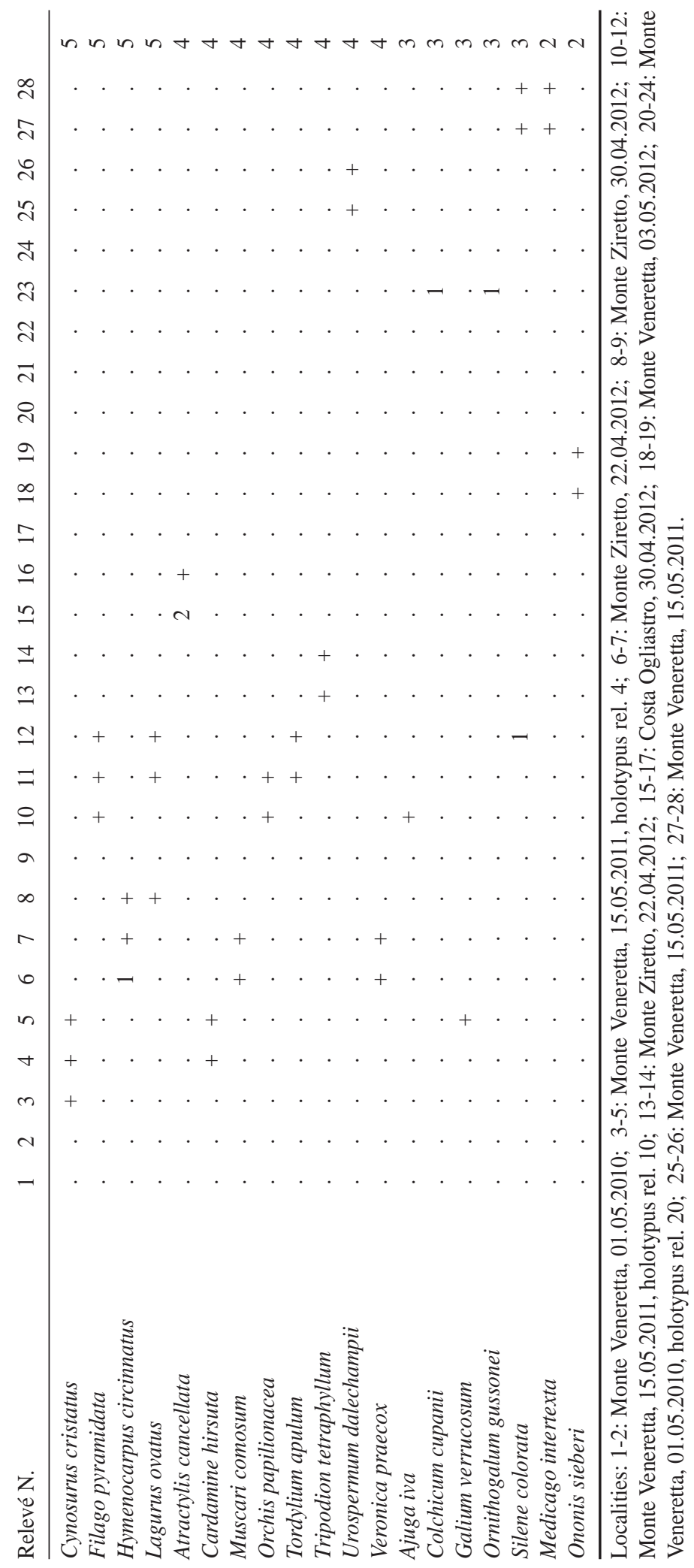


nitani (BRULlo \& al., 1998). (Table 5). This subassociation grows at altitudes of between $30 \mathrm{~m}$ and 800 metres. The floristic composition changes for Mounts Galfa in relation to a greater altitude, while for Forza D'Agrò and Capo S. Alessio, it depends on the different geological substrate (Jurassic crystalline limestones). In fact, Colymbada tauromenitana, quite thermophilous species, disappears so it is possible to recognize Erucastretum virgati typicum.

In fissures of the cliffs, in shade and nitrophilous conditions, Polypodium cambricum subsp. serrulatum grows on top of a moss carpets together with other pteridophytes, such as Ceterach officinarum and Asplenium trichomanes. From the phytosociological viewpoint, this community is attributed to Polypodietum serrati, included in the Parietarietea judaicae class, with a range of distribution in the central-western Mediterranean region (Table 5).

Chasmophilous phytocoenoses, characterized by the dominance of Cheilanthes maderensis, a rare species of great ecological and phytogeographical significance; develops on the shallow, mainly southernly exposed fissures of limestone rocks at altitudes of between $200 \mathrm{~m}$ and $800 \mathrm{me}-$ tres. This small fern is associated with Ceterach officinarum, Sedum dasyphyllum, Selaginella denticulata, etc. This community, together with Cheilanthes maderensis, is here proposed as a new association, Sedo dasyphylli-Cheilanthetum maderensis ass. nova hoc loco (Table 5, holosyntypus: rel. 21). This Sicilian association may be considered a vicariant of Umbilico rupestri-Cheilanthetum maderensis as described for the eastern sector of the Iberian Peninsula (FrANQueSA, 1995).

At lower altitudes of 50-100 metres and always on limestone substrata, Sedo dasyphilli-Cheilanthetum maderensis is replaced by a more termophylous chasmophilous community characterized by the presence of Cosentinia vellea, a rare species in Sicily, together with Sedum album, S. dasyphyllum, S. sediforme, Ceterach officinarum, etc. A new association, Sedo albi-Cosentinietum velleae ass. nova hoc loco is therefore here proposed (Table 5, holosyntypus: rel. 25). This community is similar to Cheilantho maderensis-Cosentinietum velleae Ladero ex Pérez, Díaz, Fernández \& Salvo 1989.
On sunny nitrate rich cliffs and walls, a thermo-xerophilous vegetation is localized, dominated by Capparis orientalis belonging to Capparietum rupestris. This is a nanophanerophyte which is accompanied by numerous species of the class Parietarietea judaicae, such as Parietaria judaica, Ficus carica, Centranthus ruber, Reichardia picroides, Hyoscyamus albus, Hyoseris radiata, Umbilicus horizontalis, etc. (Table 5).

On greatly inclined, shaded cliffs affected by dripping water, the vegetation Adianthum capillus-veneris grows. This is a small, widely distributed fern in the Mediterranean (DEIL, 1998) which prefers both metamorphic and limestone rocks. From a phytosociological viewpoint, these communities belong to the Eucladio-Adiantetum capilli-veneris, an association of the Adiantetea class (Table 5).

It is important to mention that in this territory, the chasmo-halophilous community of the rocky limestone coast is Limonietum ionici, described by BARTOLO \& BRULlo (1993) and widespread from Capo Taormina to Spisone (Minissale \& al., 2005). The association is characterized by $\mathrm{Li}$ monium ionicum, a strictly endemic plant of the Taormina region, together with other halophilous species, such as Limbarda crithmoides, Crithmum maritimum, Lotus cytisoides, Allium commutatum, ect.

\section{HYGROPHILOUS VEGETATION}

Both the woody and herbaceous hygrophilous vegetation of the study area is diversified in relation to water availability and human disturbance, often forming narrow bands parallel to the waterways (FoGGI \& al., 2011). Another interesting hygrophilous habitat are the temporary ponds. The floristic and structural diversity, as highlighted by cluster analysis, allows a phytosociological classification of these communities to be done (Figure 4).

Along the watercourses, a riparian wood with Salix gussonei and Platanus orientalis grows, it is ascribed to Platano-Salicetum gussonei (Table 6, Figure 4, cluster A11). In addition to the dominant species, we find in the tree layer several other hygrophilous species, such as 


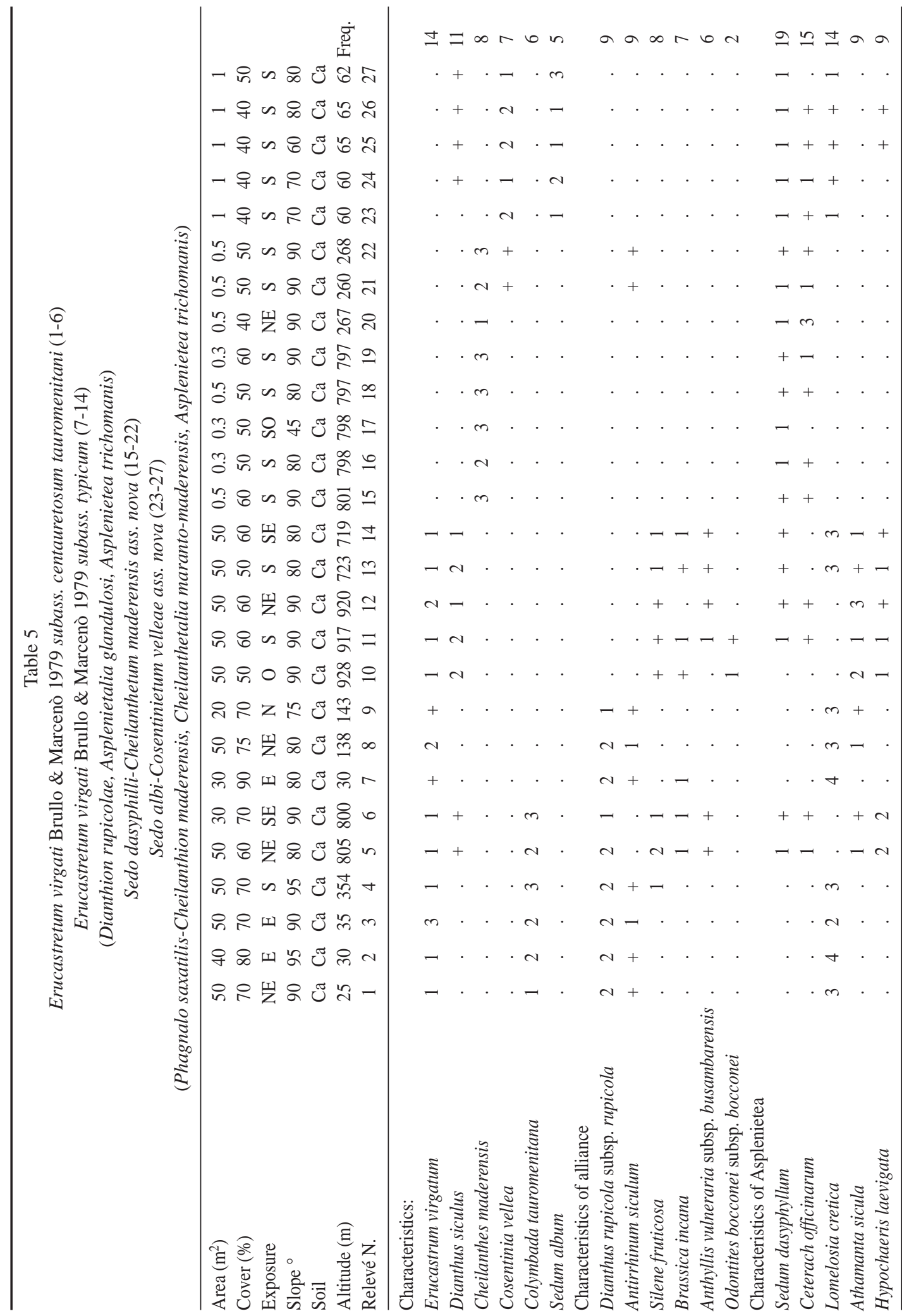




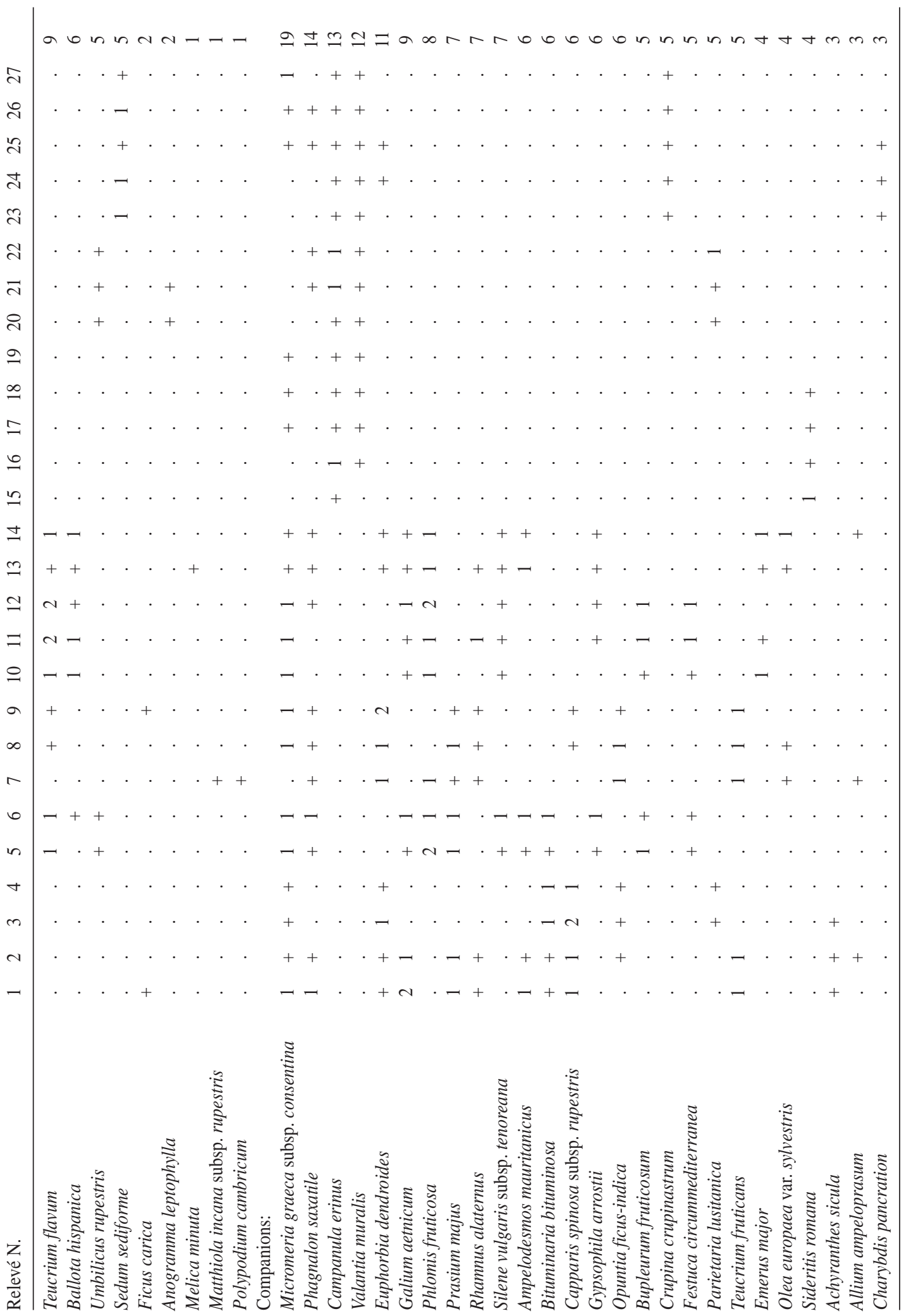




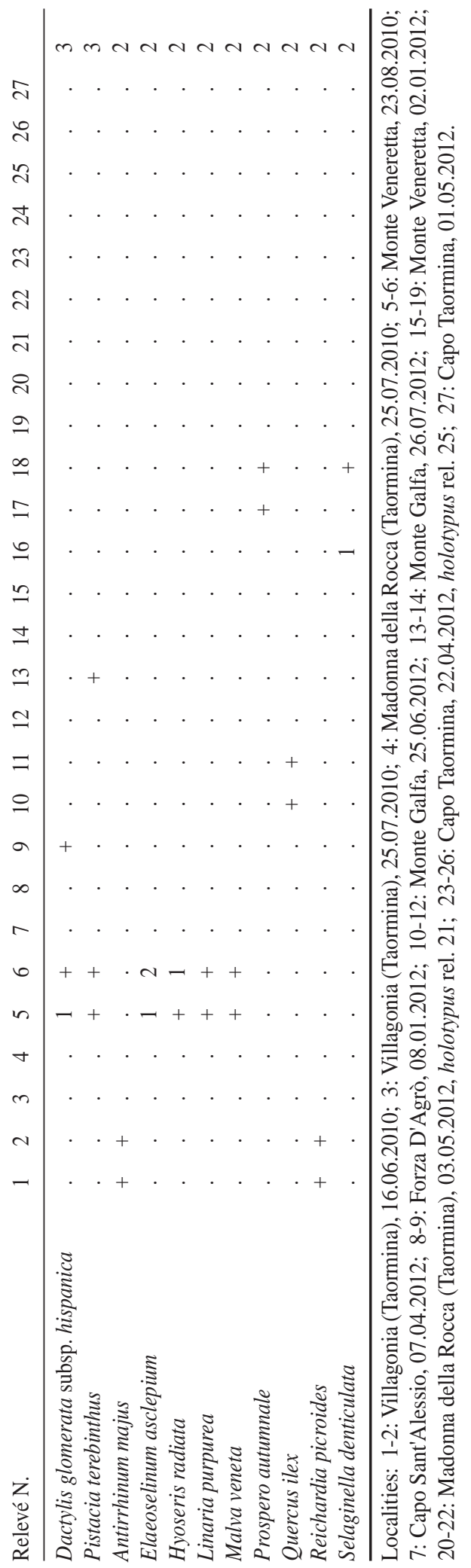




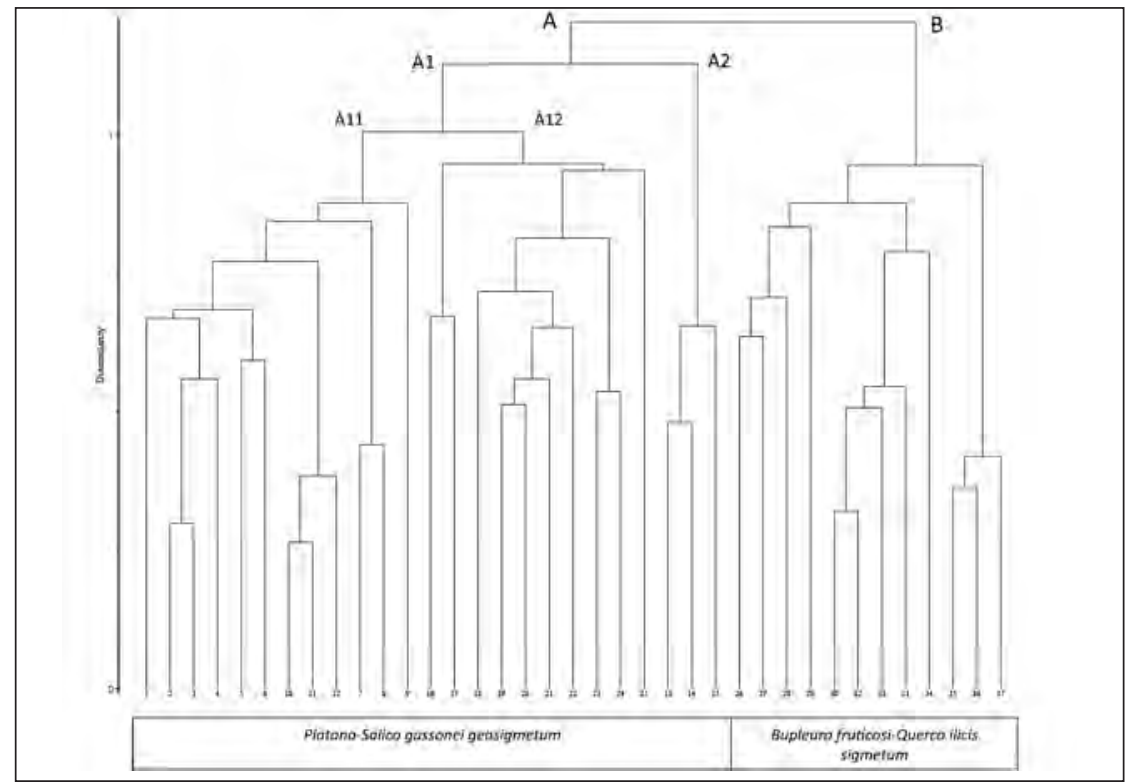

Figure 4. - Cluster analysis of the hygrophilous vegetation.

Ficus carica, Populus nigra, and Ulmus minor while in the shrub layer Hypericum hircinum subsp. majus, Rubus ulmifolius, Nerium oleander, etc. is also present. This association belongs to the Platanion orientalis alliance which is widely distributed in the southern Balkan Peninsula and Aegean area. The alliance occurs also in south-east Sicily with the association Platano-Salicetum pedicellatae (BRULlo \& SPAMPINATO, 1990). Platano-Salicetum gussonei, in the investigated territory, shows two aspects in which Platanus orientalis is always dominant (Figure 9). In the first case, it is associated with Salix gussonei and this occurs in watercourses with a greater scope and slow water flow, while in the second one, with regards to a small streams, the plane tree is associated with Fraxinus ornus, a species with a northern Mediterranean distribution and linked to less hygrophilous ecological conditions. It probably has its origins in woods which grew on the slopes and which may actually no longer be present or be severely degraded. The first case is referable to subassociation platanetosum, already reported by BRULLO $\&$ SPAMPINATO (1990) from Peloritani Mounts, while the second is here proposed as a subassociation fraxinetosum orni subass. nova hoc loco (Table 6, holosyntypus: rel.11).
As a result of the degradation of mesic woodlands, a secondary shrub develops on moist, nitrate rich soils (Figure 4, cluster A12). This vegetation is widespread in the study area, occupying in particular the north-facing slopes. From a structural viewpoint, the vegetation is characterized by intricate, almost impenetrable bushes, such as Rubus ulmifolius, Rosa sempervirens, Prunus spinosa, Hypericum hircinum subsp. majus, etc. This community is ascribed to Roso sempervirentis-Rubetum ulmifolii as described by BLASI \& al. (2001) from central Italy (Table 6). This vegetation can be considered more mesophilous than Clematido cirrhosae-Rubetum ulmifolii, an association described by GiANGUZZI \& LA Mantia (2008) for north-western Sicily. On calcareous substrates, the thinning of the riparian formations leads to the establishment of shrubs with Nerium oleander and Hypericum hircinum subsp. majus (Figure 4, cluster A3), ascribed to Rubo ulmifolii-Nerietum oleandri subass. hypericetosum maioris subass. nova hoc loco(Table 6, holosyntypus: rel. 14) vicariant of the subassociation hypericetosum hircini described by ANGIUS \& BACCHETTA (2009) from Sardinian rivers.

Developing on steep slopes overlooking the narrow incisions crossed by water courses of modest scope, is a shrub vegetation characterized by 


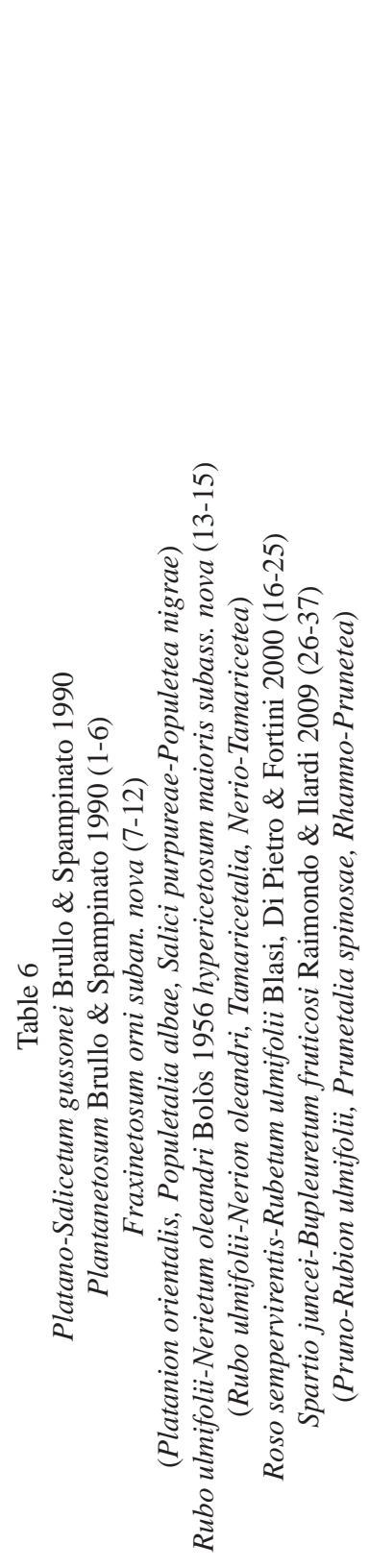

ก๓ปล $+\cdot m$

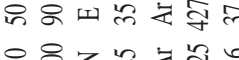

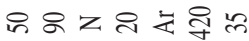

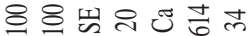

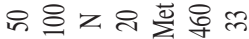

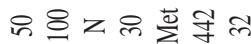
요을 离孝

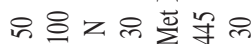

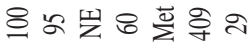

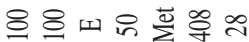

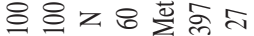
으마월윰 으의 离我兄 으은 崩离宇

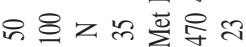

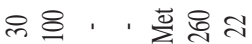

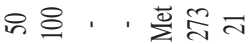
요으.' ' 离유요 용. , 离尗a

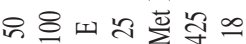

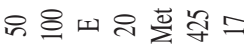

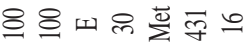

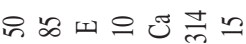
욤ㄴㅇㅢ 점 으음의 휼 으민쥬드 으은 菂离品=

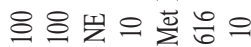

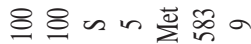

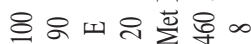

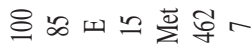
8이. 으. . , 离

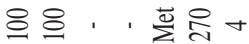
으음 제률에 유음

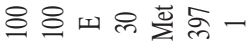

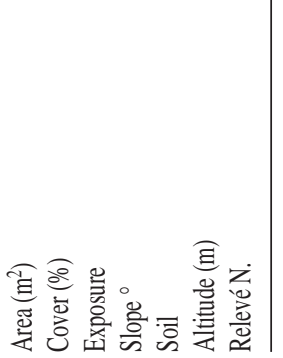

$+\cdot+$

$+m$

$\sim+\checkmark$

a.

ᄀ.

- m

入.

- . n

$-\cdot+$

$+\cdots$

$-+$$$
+
$$$$
\checkmark
$$$$
n+\cdot+\cdot \cdot+\cdot \cdot+\cdot \cdot+\cdot+\cdot+\cdot+\cdot
$$$$
\text { n }+---+-\ldots+++\ldots
$$$$
n-
$$$$
\text { n }
$$$$
++
$$$$
+
$$$$
++\cdot
$$$$
+\cdots \cdot
$$$$
m-n \cdot+\cdot+
$$$$
+-+-++
$$$$
+-+-+\cdot-+
$$$$
-m \cdot+--\cdot m+
$$$$
-n \sim
$$$$
+n-
$$$$
-n+
$$

$$
\text { in }
$$$$
-n+-
$$$$
d++c
$$$$
m \cos
$$

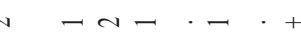$$
\text { Nin }-\mathrm{N}-+\cdot-+
$$

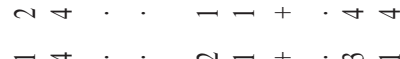$$
\alpha \text { in }
$$$$
--m+
$$$$
\text { in in }
$$$$
\text { - }
$$

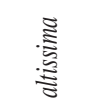

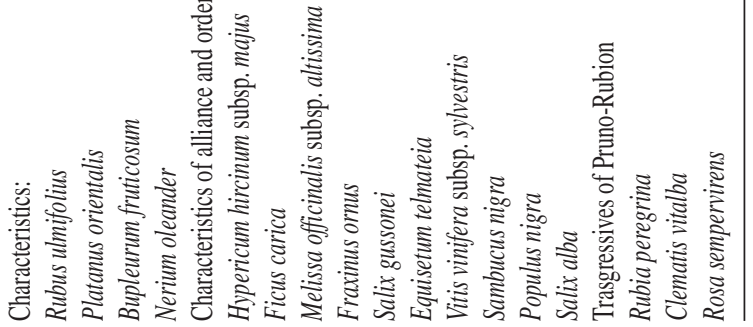




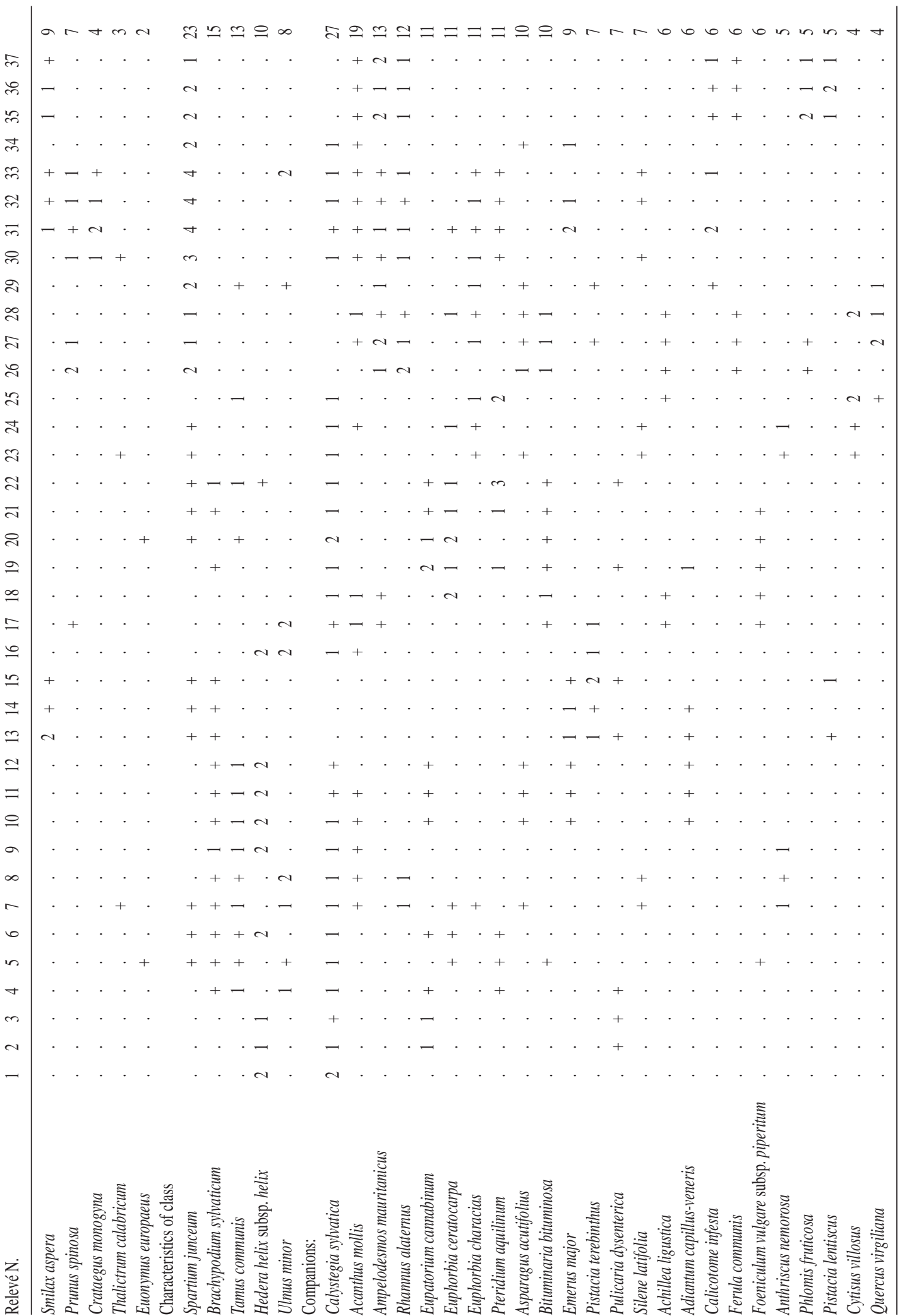




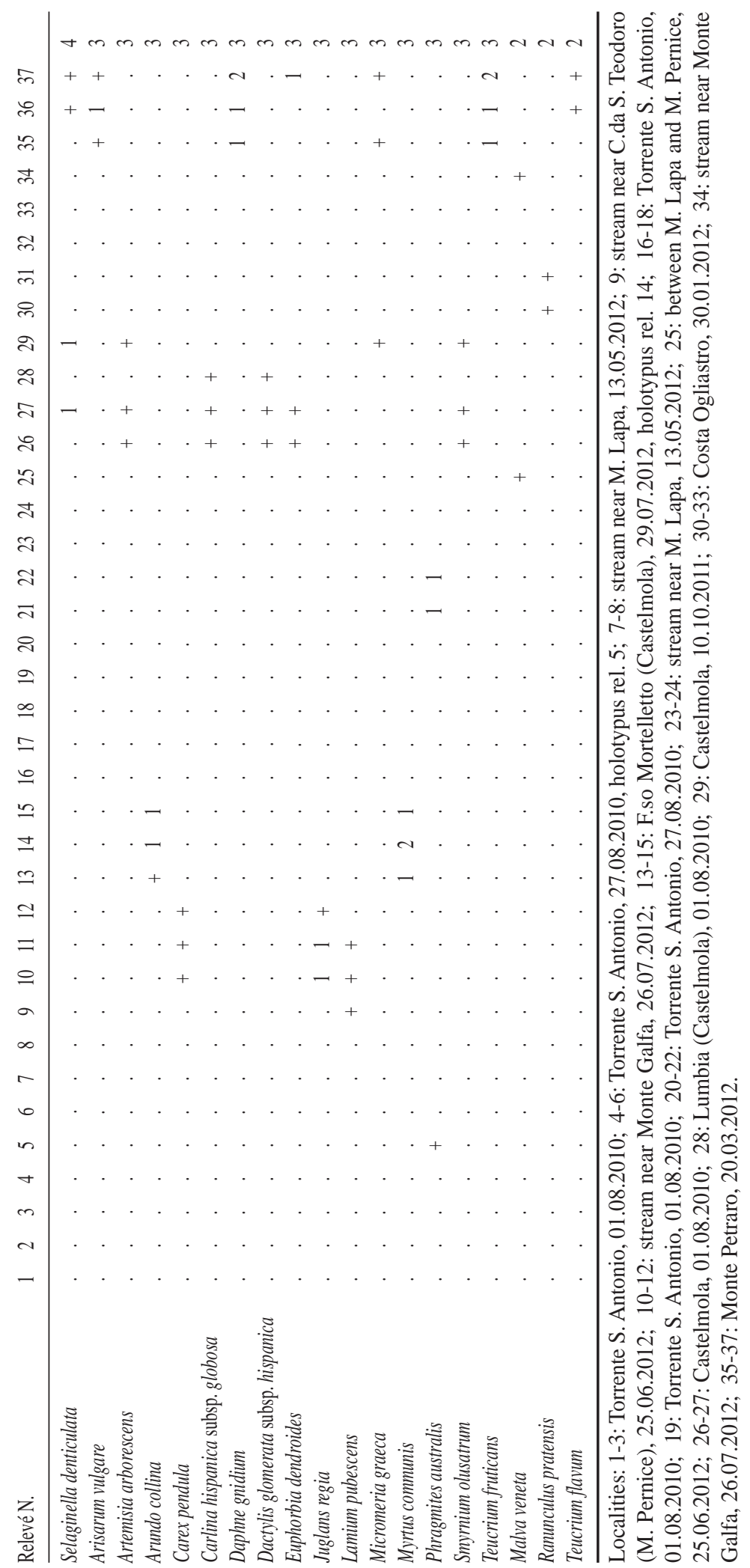




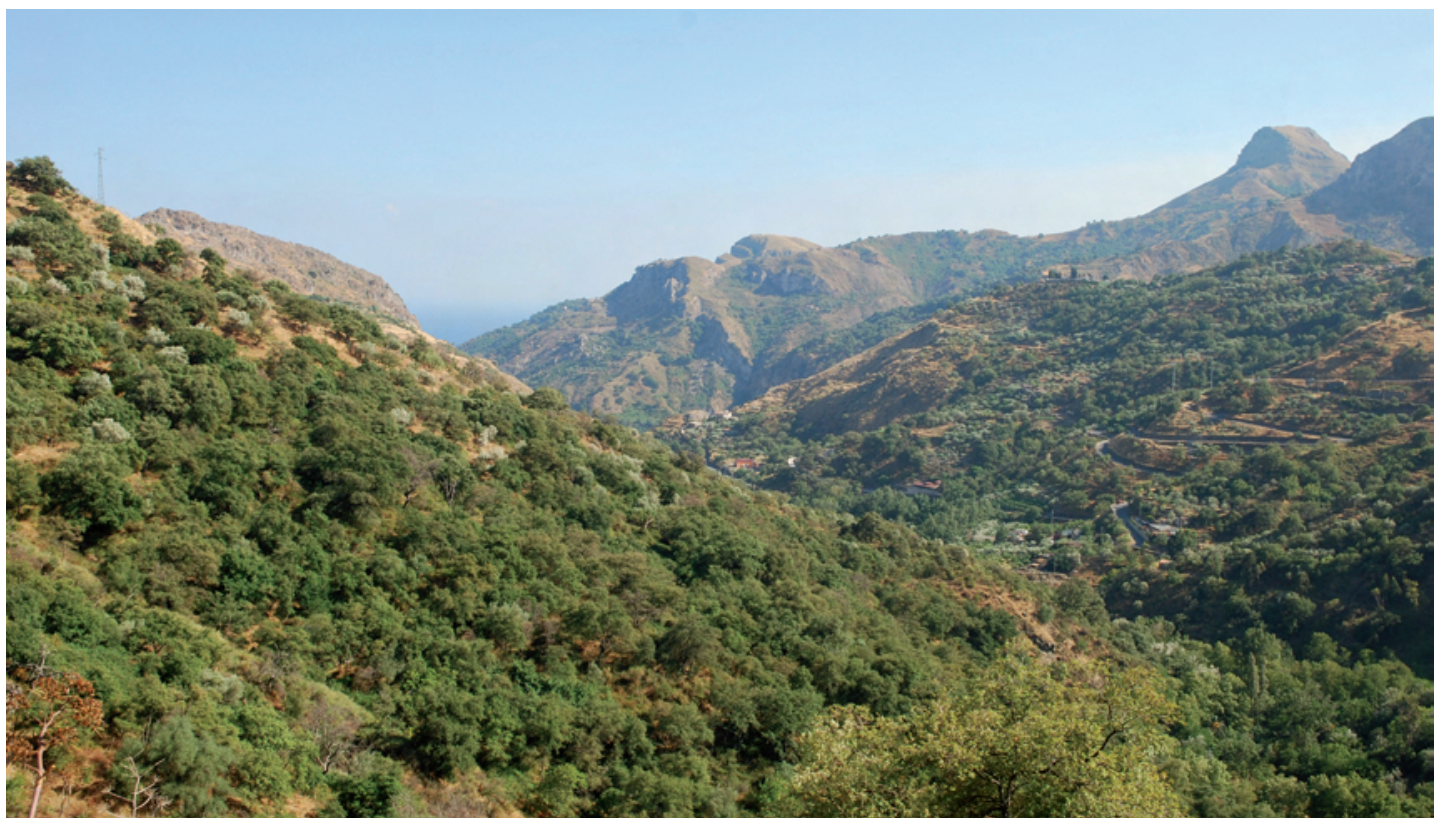

Figure 5. - Woody vegetation with Quercus virgiliana (Erico-Quercetum virgilianae) near Mongiuffi-Melia.

the dominance of Bupleurum fruticosum and Spartium junceum (Figure 4, cluster B). This vegetation is generally localized on north facing slopes up to about $900 \mathrm{~m}$ in altitude and mainly on methamorphic substrata in the bioclimatic range between the thermomediterranean upper humid belt and the mesomediterranean belt from subhumid to humid ombrotype. This vegetation, despite having different elements of Quercetea ilicis, should be placed into the Rhamno-Prunetea class due to the presence and abundance of Rubus ulmifolius and Spartium juceum. It is located between evergreen oaks forest and riparian formations. It was reported for the first time by RAIMONDO \& ILARDI (2009) in the Tyrrhenian side of the Nebrodi and Peloritani Mountains as Spartio juncei-Bupleuretum fruticosi. A similar community, for its ecology and dynamic role, Hippocrepido-Bupleuretum fruticosae is present in the Hyblaean Mountains (BRULLO \& al., 1993, 1998; Minissale \& al., 2007).

Small streams with fresh, fluent and well oxygenated waters, show the presence of Helosciadietum nodiflori. From a structural viewpoint, this vegetation tends to form large, almost floating clumps of Apium nodiflorum, together with several hygrophilous species, such as Nasturtium of- ficinale, Plantago major subsp. intermedia, Veronica anagallis-aquatica, Polypogon viridis, Persicaria laphatifolia, Mentha suaveolens, Pulicaria dysenterica, etc.

On the edge of the waterways Cirsio-Eupatorietum cannabini grows. This association is quite common along streams or small watersheds and normally occupies a narrow strip located between the watercourse and the riparian wood. From a structural viewpoint, the vegetation is characterized by many species of hygrophilous Molinio-Arrhenatheretea class, such as Eupatorium cannabinum, Cirsium creticum subsp. triumfetti, Mentha suaveolens, Hypericum hircinum subsp. majus, Juncus articulatus, Dorycnium rectum, Epilobium hirsutum, Holoschoenus australis, Agrostis stolonifera, Lytrum junceum, Paspalum paspaloides.

The small ponds, subjected to long periods of submersion, rarely dry out during the summer, and are covered by a peculiar hygrophilous vegetation, with therophytes having prostrate-ascending habitus, including Juncus bufonius, Mentha pulegium, Juncus hybridus, Polypogon maritimus, Lythrum hyssopifolia, etc. This is an amphibian annual community which prefers acidic soil and is found at altitudes above 600 metres. It has a maximum expression in the summer-autumn 
Table 7

Plantago intermediae-Cyperetum fusci ass. nova

(Nanocyperion flavescentis, Nanocyperetalia, Isöeto-Nanojuncetea)

\begin{tabular}{lccccccccc}
\hline Area $\left(\mathrm{m}^{2}\right)$ & 1 & 1 & 1 & 1 & 1 & 1 & 1 & 1 & \\
Cover $(\%)$ & 90 & 85 & 90 & 90 & 90 & 85 & 90 & 95 & \\
Exposure & 3 & 3 & - & - & 2 & 3 & 3 & 3 & \\
Slope $^{\circ}$ & $\mathrm{N}$ & $\mathrm{N}$ & - & - & $\mathrm{N}$ & $\mathrm{N}$ & $\mathrm{O}$ & $\mathrm{O}$ & \\
Altitude $(\mathrm{m})$ & 679 & 678 & 678 & 679 & 677 & 662 & 654 & 654 & Freq \\
Relevé N. & 1 & 2 & 3 & 4 & 5 & 6 & 7 & 8 & \\
\hline
\end{tabular}

Characteristics:

Plantago intermedia

Cyperus fuscus

Characteristics of class and alliance

Juncus bufonius

Mentha pulegium

Lythrum hyssopifolia

Polypogon maritimus

Juncus hybridus

Lotus angustissimus

Companions:

Polypogon viridis

Juncus articulatus

Trifolium resupinatum

Samolus valerandi

\begin{tabular}{|c|c|c|c|c|c|c|c|c|}
\hline 1 & 2 & 2 & 1 & + & 3 & . & . & 6 \\
\hline 3 & 2 & 2 & 2 & 4 & 3 & 3 & 2 & 8 \\
\hline 3 & 2 & 3 & 3 & 1 & + & 1 & + & 8 \\
\hline 3 & 2 & 3 & 1 & 1 & + & 2 & 4 & 8 \\
\hline 2 & 3 & 2 & 2 & 2 & . & + & . & 6 \\
\hline+ & + & + & + & + & + & . & . & 6 \\
\hline 1 & + & 1 & + & . & 2 & . & . & 5 \\
\hline . & . & . & . & . & . & + & + & 2 \\
\hline 1 & 1 & 2 & 1 & 1 & 1 & + & + & 8 \\
\hline+ & 1 & . & . & + & + & 1 & + & 6 \\
\hline . & . & . & . & . & + & + & + & 3 \\
\hline . & . & . & . & . & + & + & . & 2 \\
\hline
\end{tabular}

Companions: Epilobium parviflorum and Eupatorium cannabinum + in 1; Hypericum hircinum subsp. majus + in 4. Localities: 1-4: Monte Veneretta, 24.07.2011, holotypus ass. rel. 1; 5: Monte Veneretta, 10.10.2011; 6: Monte Veneretta, 11.08.2012; 7-8: Monte Lapa, 11.08.2012.

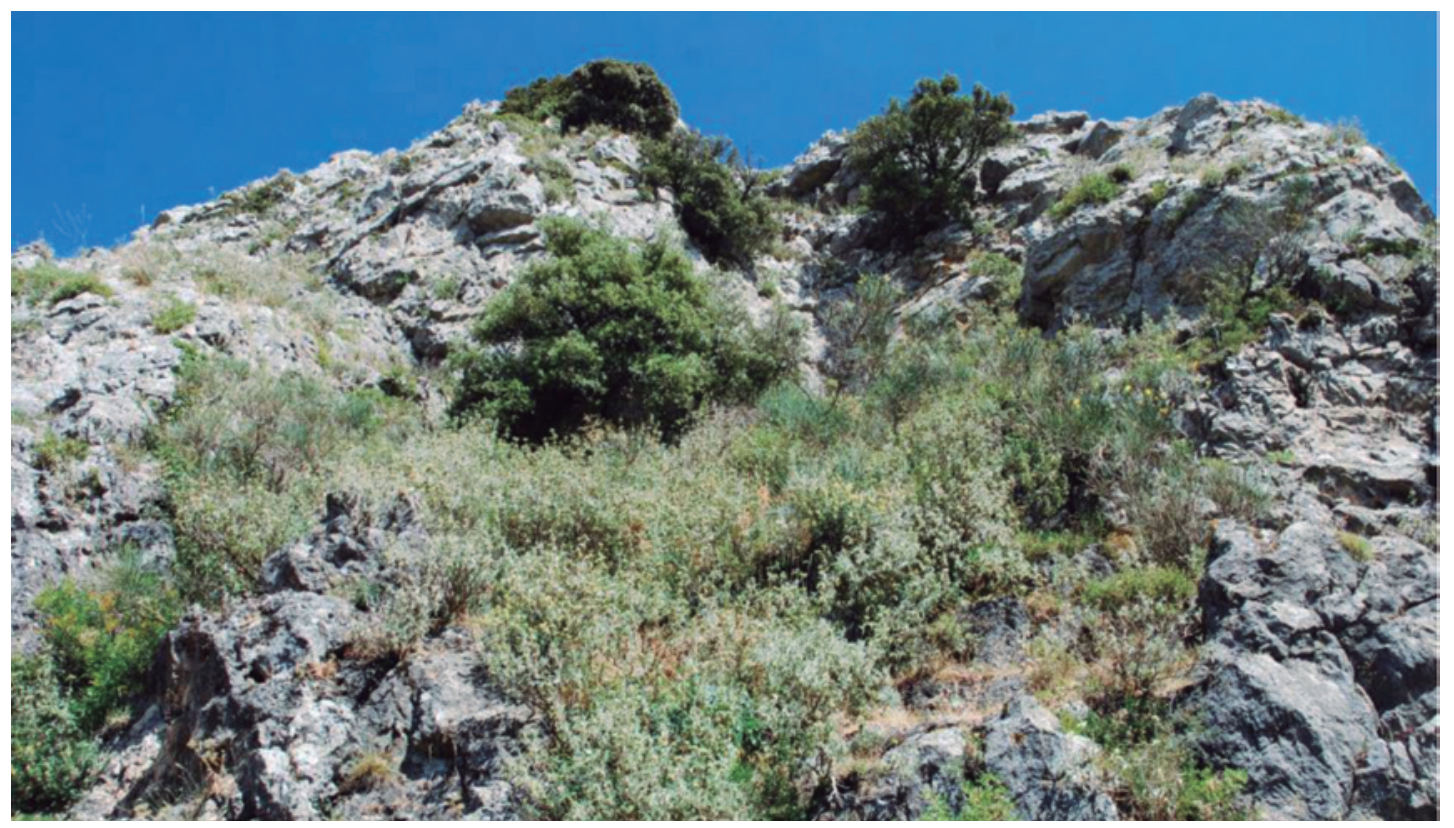

Figure 6. - Low-shrub vegetation with Phlomis fruticosa and Micromeria graeca subsp. consentina (Micromerio consentinae-Phlomidetum fruticosae) on limestone outcrops of M. Galfa, Quercus ilex on the top. 


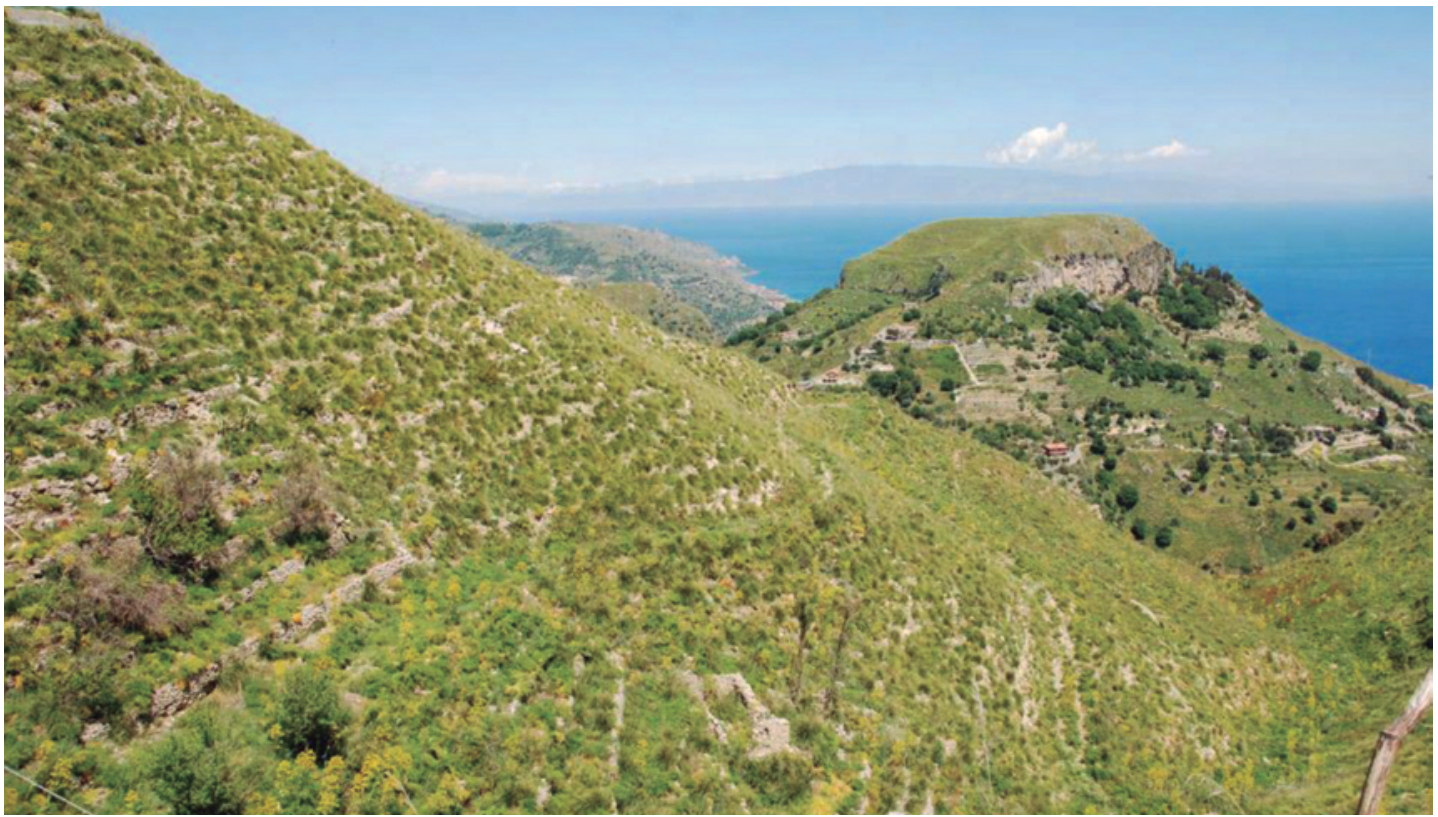

Figure 7. - Perennial dry grassland plant communities with Ampelodesmos mauritanicus (M. Veneretta and M. Ziretto).

period, when the soil surfaces are still more or less moist, but not submerged. The presence of Cyperus fuscus and Plantago intermedia, is significant because they belonging to the Nanocyperetalia order, with a Central-European and Atlantic distribution while in the Mediterranean regions penetrations are limited to mountainous areas (BRUllo \& Minissale, 1998). For its floristic peculiarity, this community is here proposed as a new association, named Plantago intermediae-Cyperetum fusci (Table 7, holosyntypus: rel.1).

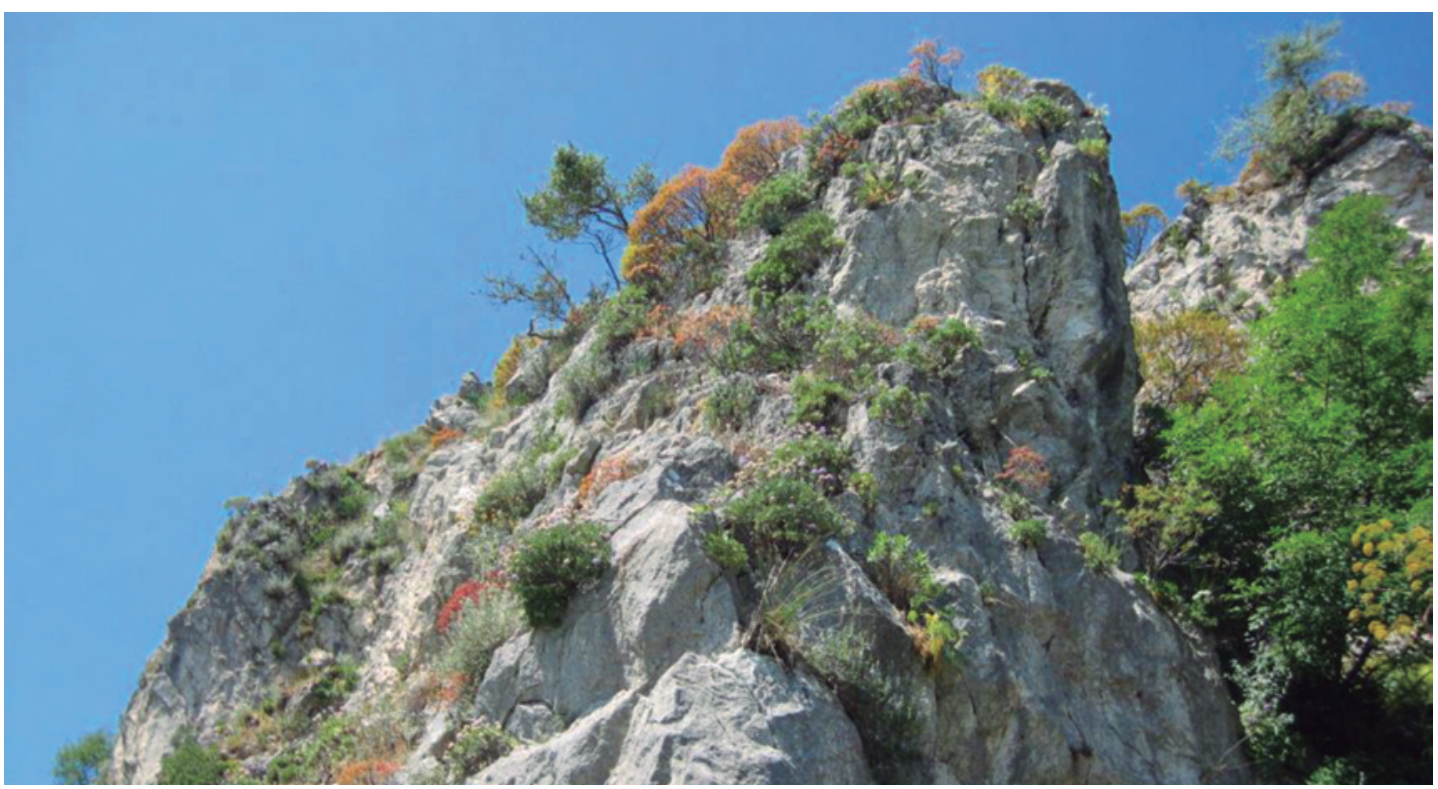

Figure 8. - Rupicolous vegetation with Lomelosia cretica and Colymbada tauromenitana (Erucastretum virgati subass. centauretosum tauromenitani) on limestones outcrops of M. Lapa. 


\section{SINDYNAMIC FEATURES}

The floristic composition of the plant communities is the expression of several ecological factors, such as the nature of the substrate, soil depth, climate and, in particular, meso- and micro-climatic conditions (RIVAS-MARTíNEZ, 2005; MiNISSALE \& SCIANDRELLO, 2013). This is particularly evident in the Taormina region where abiotic conditions vary depending on altitude and the exposure of slopes since the territory has a somewhat rough geomorphology with reliefs characterized by steep, furrowed slopes with occasional deep incisions.

Human activity overlaps with abiotic factors to contribute strongly in the shaping of the landscape (Figure 7). This is evident in the study area where human influence has occurred with remarkable intensity for more than two millennia, especially by grazing, bushfires and timber logging which has led to the emergence and spread of the degradation of the natural vegetation (TOMASELLI \& al., 2012). Only in the last few decades a partial change of land use has occurred. Two opposite trends can be observed: the abandonment of cultivation over vast hilly areas which have promoted the recovery and reaffirmation of woody vegetation; and intense urbanization of the coastal strip and around the town of Taormina, which has excluded any possibility of vegetation recovery.

The analysis of the dynamic relationships observed between the various phytocoenoses detected in the study area has allowed the identification of a vegetation series, which, in agreement with RIVAS-MARTínEZ (2005), can be distinguished in the climatophilous, edaphoxerophilous, and edaphohygrophilous series and also the perma-series. The analysis of the vegetation series allows the potential of plant communities, which make up the current patchwork of landscape to be evaluated in order to plan environmental restoration or recovery of the vegetation cover. The identified series highlighting each step and the mature plant communities associated with them are described below.

\section{Climatophilous vegetation}

\section{Acidophilous series of metamorphic substrates (Erico arboreae-Querco virgilianae sigmetum)}

In places with deep, well-drained soils, ranging from flat to more or less inclined, the climatophi-

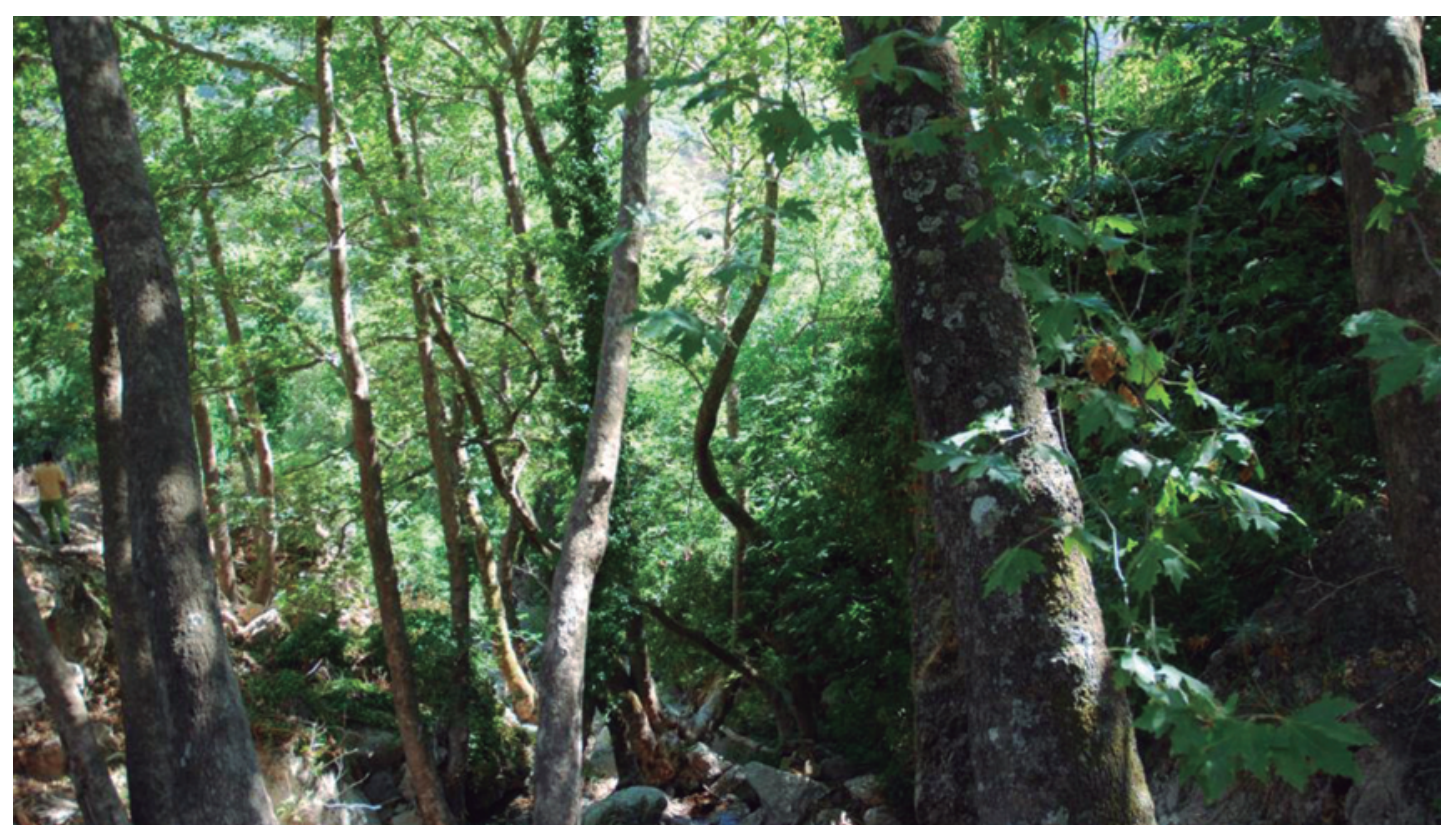

Figure 9. - Riparian wood with Salix gussonei and Platanus orientalis (Platano-Salicetum gussonei) at base of M. Galfa. 
lous vegetation is represented by Erico arboreaeQuercetum virgilianae. This series had been identified for this territory by BAZAN \& al. (2010) where they indicate the substrates acids of northeastern Sicily at altitudes between $200 \mathrm{~m}$ and $1200 \mathrm{~m}$. In the territory examined, these thermophilous woods represent the potential vegetation even at altitudes close to sea level. They however remain allocated on the cooler and wet slopes on northern exposure.

The degradation of these woodlands as a result of disturbances, such as bushfires and logging, determines the establishment of secondary scrub with the dominance of Calicotome infesta and Cistus salviifolius, here referred to as Cisto salviifolii-Calicotometum infestae. The repetition of bushfires determines the success of Ampelodesmos mauritanicus grasslands, referred to as Galio-Ampelodesmetum mauritanici, in deep soil reaches and acidophilus arid grasslands related to Loto conimbricensis-Tuberarietum plantagineae in places with strongly eroded surface soils.

\section{Basophilous series of sedimentary substrates (Oleo-Querco virgilianae sigmetum)}

In the examined area, it was not possible to detect woodlands of deep soils derived from sedimentary carbonate rocks but only isolated individuals of Quercus virgiliana. In those few areas with deep soils originated from sedimentary rocks, it can be argued that bioclimatic conditions favour the deciduous oak forest related to OleoQuercetum virgilianae. These thermophilous woods represent the vegetation potential on substrates not suitable for the acidophilous species. The degradation of this vegetation after disturbances such as bushfires and logging has led to the establishment of the secondary maquis represented by Teucrio-Rhamnetum alaterni. The frequent occurance of bushfires has resulted in the emergence of grasslands with Ampelodesmos mauritanicus (Seselio-Ampelodesmetum mauritanici) in deep soil reaches, mixed with ephemeral arid grasslands of Trachynion distachyae (Astragalo sesamaei-Medicaginetum rectae) where the soil is shallower.

\section{EDAPHIC VEGETATION}

\section{Edaphomesophilous series of semirupestrian ma- quis (Bupleuro fruticosi-Querco ilicis sigmetum)}

This series is observed on the slopes and rocky debris that occurs at the base of the limestone hills, such as Mount Veneretta, M. Lapa, M. Ziretto, and M. Galfa. These locations are subjected to humid currents that rise up from the Ionian Sea. The head of the series is represented by Quercus ilex woody communities related to Bupleuro fruticosae-Quercetum ilicis, which normally occurs from $500 \mathrm{~m}$ up to the highest altitudes, although it could grow at lower altitudes $(300 \mathrm{~m})$ when exposed to the north in narrow valleys. This vegetation, due to human disturbance, is connected with various secondary aspects, as the low scrub of Micromerio consentinae-Phlomidetum fruticosae in rocky walls and arid locations, and Spartio juncei-Bupleuretum fruticosae in cooler rock stations close to watercourses. The start of the degradation processes of these communities leads to thinning of the shrubs and this phenomenon facilitates the establishment of other more resistant species to disturbances (Figure 6).

The replacement of this vegetation with grasslands of Seselio-Ampelodesmetum mauritanici occurs at the highest altitudes, while on sunny lower altitudes slopes Ferulo communi-Hyparrhenietum hirtae grows. On shallow soil with rock outcrops, disturbances favour the establishment of ephemeral grassland of the Stipo-Trachynietea distachyae class, such as Astragalus sesamaei-Medicaginetum rectae from low altitudes up to 800 metres and lawns dominated by Trifolium subterraneum, referable to Poo bulbosae-Trifolietum subterranei plantaginetosum serrariae at the highest altitudes of less drained and more compact soils.

\section{Edapho-hygrophylous geoseries of rivers and streams (Platano-Salico gussonei geosigmetum)}

The streams are affected by hygrophilous woody vegetation, represented by Platano-Salicetum gussonei (Figure 9). This association in the Peloritani region is represented by two facies, the 
first one with Plantanus orientalis of watercourses with greater scope, the second one with Fraxinus ornus linked to small streams. This vegetation, due to various disturbances (fire, landfills, pollution, water captations, etc.) is replaced by shrub formations ascribed to Roso-Rubetum ulmifolii which normally forms the mantle preforestal. The woody vegetation is normally associated with hygrophylous herbaceous communities, in relation to ecological factors that vary from the shore of the watercourse to inside the water. In open areas with significant soil and water availability, hydric herbaceous formations of Cirsio-Eupatorietum cannabini are established while waterbanks characterized by a slow but steady water flow are populated by Helosciadietum nodiflori. The edges of small streams at higher altitudes are populated by amphibian communities of Cyperus fuscus related to Plantago intermediae-Cyperetum fusci.

\section{PERMASERIES}

Chasmophilous permaseries of cliffs (Erucastro virgati permasigmetum, Limonio ionici permasigmetum)

The limestone cliffs, at altitudes ranging from $50 \mathrm{~m}$ and $1000 \mathrm{~m}$ above sea level, are populated by chasmophilous vegetation ascribed to Erucastretum virgati, by phytocoenosis up to $800 \mathrm{~m}$ and dominated by Colymbada tauromenitana, while at higher altitudes it is replaced by Dianthus siculus. This community is mixed with microphytic chasmophilous vegetation of Sedo dasyphilliCheilanthetum maderensis and Sedo albi-Cosentinietum velleae localized in small crevices of the cliffs and with the comophilous community of Polypodietum serratae, found on small rocky crags. It is also in contact with the stain rock of Euphorbietum dendroidis, localized on walls and not so steep slopes with aspects of the series of Bupleuro-Quercetum ilicis (Figure 8).

Frequently, the outcrop of aquifers, through the phenomena of dripping, favours the growth of Eucladio-Adiantetum. On rocky coasts, the permaseries is instead characterized by Limonietum ionici.

\section{Semirupestrian maquis (Euphorbio dendroidis permasigmetum)}

On the more or less inclined and sunny limestone cliffs, the climax vegetation is represented by the maquis of Euphorbietum dendroidis. It usually occurs from sea level up to altitudes of $600 \mathrm{~m}$ on very sunny slopes, otherwise the holm oak series takes over. On the whole, it is quite resistant to human activities: only when the disturbance is very intense is this shrub community replaced by sparse grassland of Hyparrhenia hirta. The increase of nitrophilous conditions leads to the onset of vegetation with Artemisia arborescens in which some invasive species are frequent such as Opuntia ficus-indica, Lantana camara, Rhus coriaria, etc.

\section{CONCLUSIONS}

The framework of the vegetation so far outlined has highlighted the great diversity of the plant landscape. It is characterized by a climatophilous series of metamorphic substrates and another less common one of limestone substrates. The latter is characterized by several edaphic series reflecting not only the articulated geomorphology but also the climatic conditions, which are subjected to significant changes especially in relation to altitudinal gradient and exposure.

This biodiversity should be protected and managed with targeted actions (SCIANDRELLO \& TOMASELLI, 2011; GianguZZI \& al., 2010). In this regard, it should be highlighted that the studied area, for a large part, falls into Sites of Community Importance, a system of protected areas for which conservation measures are not only appropriate but required by management plans for $\mathrm{Na}-$ tura 2000 sites and recently approved by the Regional authority of Sicily (PAVONE \& al., 2007).

Nowadays, the main threat to the area is excessive, uncontrolled bushfires and pastoral activity connected with it. Grazing following bushfires promotes, on the one hand, the development and dissemination of ephemeral spring lawns and perennial grasslands while, on the other, results in 
the elimination of the more mature communities represented by the maquis or the wood. The result is a drastic reduction of the woodland cover, an accelerated erosion processes and an overall loss of biodiversity value, etc. Therefore, the main conservation measures of the flora and plant communities should be targeted especially to the regulation of grazing and, above all, a preventive program regarding summer bushfires. In general, the establishment of processes to promote the development of economic activities compatible with the conservation objectives of the area should be set in place. Identifying actions to enhance com- munication and increase awareness and knowledge about environmental habitats should also be carried out. Finally, in order to better preserve this precious natural landscape, it would be desirable to establish a Nature Reserve through a managing body qualified to protect this biodiversity hot spot.

\section{ACKNOWLEDGMENTS}

The authors wish to thank anonymous referees for their valuable suggestions.

\section{SYNTAXONOMIC SCHEME}

\section{Climatophilous vegetation}

QUERCETEA ILICIS Br.-Bl. ex A. \& O. Bolòs 1950

Quercetalia calliprini Zohary ex Quézel et al. 1992

Oleo sylvestris-Ceratonion siliquae Br.-Bl. ex Guinochet \& Drouineau 1944 em. Rivas-Martínez 1975

Euphorbietum dendroidis Guinochet in Guinochet \& Drounieau 1944

Teucrio fruticantis-Rhamnetum alaterni Brullo, Minissale, Scelsi \& Spampinato 1993

Cisto salviifolii-Calicotometum infestae ass. nova hoc loco

Micromerio consentinae-Phlomidetum fruticosae ass. nova hoc loco

Micromerio consentinae-Phlomidetum fruticosae odontidetosum bocconei subass. nova

Quercetalia ilicis Br.-B1. ex Molinier 1934 em. Rivas-Martínez 1975

Quercion ilicis Br.-B1. ex Molinier 1934

Bupleuro fruticosi-Quercetum ilicis ass. nova hoc loco

Oleo-Quercetum virgilianae Brullo 1984

Erico arboreae-Quercion ilicis Brullo, Di Martino \& Marcenò 1977

Erico arboreae-Quercetum virgilianae Brullo \& Marcenò 1985

\section{PERENNIAL AND ANNUAL DRY GRASSLAND}

LYGEO-STIPETEA Rivas-Martínez 1978

Hyparrhenietalia Rivas-Martínez 1978

Avenulo-Ampelodesmion mauritanici Minissale 1995

Galio aetnici-Ampelodesmetum mauritanici Minissale 1995

Seselio tortuosi-Ampelodesmetum mauritanici Minissale 1995

Hyparrhenion hirtae Br.-Bl., P. Silva \& Rozeira 1956

Ferulo communis-Hyparrhenietum hirtae Brullo \& Siracusa 1996

Arundion collinae Brullo, Giusso, Guarino \& Sciandrello 2010

Euphorbio ceratocarpae-Arundinetum collinae Brullo, Giusso, Guarino \& Sciandrello 2010

Aristido caerulescentis-Hyparrhenion hirtae Brullo, Scelsi \& Spampinato 1997

Cenchro ciliaris-Hyparrhenietum hirtae Wildpret \& Rodriquez in Rivas-Martínez \& al. 1993 
ONOPORDETEA ACANTHII Br.-Bl.1964

Carthametalia lanati Brullo in Brullo \& Marcenò 1985

Silybo-Urticion Sissing ex Br.-Bl. \& O. Bolòs 1958

Cynara cardunculus comm.

Poetea bulbosae Rivas Goday \& Rivas-Martínez in Rivas-Martínez 1978

Poetalia bulbosae Rivas Goday \& Rivas-Martínez in Rivas Goday \& Ladero 1970

Trifolio subterranei-Periballion Rivas Goday 1964

Poo bulbosae-Trifolietum subterranei Rivas Goday 1964 plantaginetosum serrariae subass. nova

Tuberarietea Guttatae (Br.-Bl. in Br.-Bl. \& al. 1952) Rivas Goday \& Rivas-Martínez 1963

Tuberarietalia guttatae Br.-B1. in Br.-B1. \& Wagner 1940

Tuberarion guttatae Br.-Bl. in Br.-Bl. \& Wagner 1940

Loto conimbricensis-Tuberarietum plantagineae ass. nova hoc loco

STIPo-TRACHYNIETEA DISTACHYAE Brullo in Brullo, Scelsi \& Spampinato 2001

Trachynietalia distachyae Rivas-Martínez 1978

Trachynion distachyae Rivas-Martínez 1978

Astragalo sesamaei-Medicaginetum rectae ass. nova

\section{Cliff Vegetation}

Asplenietea tRICHOMAnis (Br.-Bl. in Meier \& Br.-Bl. 1934) Oberd. 1977

Asplenietalia glandulosi Br.-Bl. in Meier \& Br.-Bl. 1934

Dianthion rupicolae Brullo \& Marcenò 1979

Erucastretum virgati Brullo \& Marcenò 1979

subass. typicum

subass. centauretosum tauromenitani Pirola ex Brullo \& Marcenò 1979

Cheilanthetalia maranto-maderensis Sáenz de Rivas \& Rivas-Martínez 1979

Phagnalo saxatilis-Cheilanthion maderensis Loisel 1970 corr. Pérez-Carro \& al. 1989

Sedo dasyphilli-Cheilanthetum maderensis ass. nova hoc loco

Sedo albi-Cosentinietum velleae ass. nova hoc loco

Tortulo-Cymbalarietalia Segal 1969

Parietarion judaicae Segal 1969

Capparietum rupestris O. Bolòs \& Molinier 1958

ANOMODONTO-POLYPODIETEA Rivas-Mart. 1975

Anomodonto-Polypodietalia serrati O. Bolòs \& Vives in O. Bolòs 1957

Polypodion serrati Br.-Bl. in Br.-Bl., Roussine \& Négre 1952

Polypodietum serrati Br.-Bl. in Br.-B1., Roussine \& Négre 1952

CRITHMo-Limonietea Br.-Bl. in Br- Bl., Roussine \& Nègre1952

Crithmo-Limonietalia Molinier 1934

Crithmo-Limonion Molinier 1934

Limonietum jonici Bartolo \& Brullo 1993

AdIANTETEA B1.-B1. 1948

Adiantetalia Br.-B1. ex Horvatic 1934

Adiantion Br.-Bl. ex Horvatic 1934

Eucladio-Adiantetum capilli-veneris Br.-Bl. ex Horvatic 1934 


\section{HYGROPHILOUS VEGETATION}

SAlici PRUPUREaE-Populetea NigRaE (Rivas-Mart. et Cantó ex Rivas-Mart. et al. 1991) Rivas-Mart. et Cantó in Rivas-Mart. et al. 2002

Populetalia albae Br.-Bl. ex Tchou Yen Tchen 1948

Platanion orientalis I. Kárpáti \& V. Kárpáti 1961

Platano-Salicetum gussonei Brullo \& Spampinato 1990

subass. platanetosum Brullo \& Spampinato 1990

subass. fraxinetosum orni subass. nova hoc loco

NERIO-TAMARICETEA Br.-Bl. \& O. Bolòs 1958

Tamaricetalia Br.-Bl. \& O. Bolòs 1958

Rubo ulmifolii-Nerion oleandri O. Bolòs 1985

Rubo ulmifolii-Nerietum oleandri Bolòs 1956

subass. hypericetosum maioris subass. nova hoc loco

Rhamno-PRunetea Rivas Goday \& Borja ex Tüxen 1962

Prunetalia spinosae Tüxen 1952

Pruno-Rubion ulmifolii O. Bolòs 1954

Roso sempervirentis-Rubetum ulmifolii Blasi, Di Pietro \& Fortini 2000

Spartio juncei-Bupleuretum fruticosi Raimondo \& Ilardi 2009

Phragmito-MaGNo-CARICETEA Klika in Klika \& Novák 1941

Nasturtio-Glycerietalia Pignatti 1953

Nasturtion officinalis Géhu \& Géhu-Franck 1987

Helosciadietum nodiflori Maire 1924

MoLINIO-ARRHENATHERETEA Tx.1937

Plantaginetalia majoris Tx. \& Preising in Tx. 1950

Mentho-Juncion inflexi De Foucault 1984

Cirsio-Eupatorietum cannabini Brullo \& Spampinato 1990

Isoeto-NANoJunCETEA Br.-Bl. \& Tx. ex Br.-Bl., Roussine et Nègre 1952

Nanocyperetalia Klika 1935

Nanocyperion Koch 1926

Plantago intermediae-Cyperetum fusci ass. nova hoc loco

\section{REFERENCES}

Angius, R. \& Bacchetta, G. - 2009- Boschi e boscaglie ripariali del Sulcis-Iglesiente (Sardegna sud-occidentale, Italia) - Braun-Blanquetia 45: 3-62.

Bazan, G., Brullo, S., Raimondo, F.M. \& Schicchi, R. 2010 — Le serie di vegetazione della regione Sicilia In: Blasi, C. (Ed.). La vegetazione d'Italia. Pp. 428-469. Palombi Editori, Roma.

Biondi, E. - 2011 - Phytosociology today: Methodological and conceptual evolution — Plant Biosyst. 145: 19-29.

Biondi, E. \& Guerra, V. — 2008 - Vegetazione e paesaggio vegetale delle gravine dell' arco jonico — Fitosociologia 45(1) Suppl. 1: 57-125.

Blasi, C., Di Pietro R., \& Fortini P. - 2000- A phytosociological analysis of abandoned terraced olive grove shrublands in the Tyrrhenian district of Central Italy Plant Biosyst. 134 (3): 305-331.

Blasi, C., Marignani, M., Copiz, R., Fipaldini, M., Bonacquisti, S., Del Vico, E., Rosati, L. \& Zavattero, L. 2011- Important Plant Areas in Italy: From data to mapping — Biol. Conserv. 144 (1): 220-226. 
Braun-Blanquet, J. —1964- Pflanzensoziologie. Grundzuge der Vegetations-kunde - Springer Verlag. Wien.

Brullo, S. \& Guarino, R. - 2002 - La classe Parietarietea judaicae in Italia - Fitosociologia 39 (1) Suppl. 2: 527.

Brullo, S., Gianguzzi, L., La Mantia, A. \& Siracusa, G. 2008 - La classe Quercetea ilicis in Sicilia — Boll. Acc. Gioenia. Sci. Nat. 41 (369): 1-124.

Brullo, S., Marcenò, C. \& Siracusa G. - 2004 — La classe Asplenietea trichomanis in Sicilia - Coll. Phytosoc. 28: 467-538.

Brullo, S. \& Marcenò, C. —-1985- Contributo alla conoscenza della classe Quercetea ilicis in Sicilia — Not. Fitosoc. 19(1): 183-229.

Brullo, S. \& Minissale, P. - 1998 - Considerazioni sintassonomiche sulla classe Isoeto-Nanojuncetea - Itinera Geobot. 11: 263-290.

Brullo, S., Scelsi, F., Siracusa \& G. Spampinato, G. 1996- Caratteristiche bioclimatiche della Sicilia Giorn. Bot. Ital. 130 (1): 177-185.

Brullo, C., Brullo, S., Giusso Del Galdo, G. \& Sciandrello, S. -2011- Taxonomical, morphological and geobotanical considerations on Seseli tortuosum L. (Apiaceae) from Sicily — Phyton 51(2): 201-210.

Brullo, C., Brullo, S., Giusso Del Galdo, G., Guarino, R., Minissale, P., Scuderi, L., Siracusa, G., Sciandrello, S. \& Spampinato, G. — 2010 - The Lygeo-Stipetea class in Sicily - Ann. Bot. (Roma) 0: 1-31.

Brullo, S., Minissale, P., Giusso Del Galdo, G., Siracusa, G. \& Spampinato, G. - 2002-Considerazioni sintassonomiche e fitogeografiche sulla vegetazione della Sicilia — Boll. Acc. Gioenia. Sci. Nat. 35 (361): 325-359.

Brullo, S., Scelsi, F., Siracusa, G. \& Tomaselli, V. —1998Considerazioni sulla vegetazione delle vulcaniti di Monte Lauro (Sicilia meridionale) e sue correlazioni edafiche - Boll. Acc. Gioenia Sci. Nat. 29(352): 169184.

Cano, E., Ladero, M., García-Fuentes, A., Pinto-Gomes, C.J. \& Cano-Ortiz, A. - 2007-Current state of the Poetea bulbosae class in the Iberian Peninsula - Phytocoenologia 37(3-4): 645-661.

Catalano, S. - 2010 — Note illustrative della Carta Geologica d'Italia alla scala 1:50.000. foglio 613 Taormina Ispra, S.EL.Ca, Firenze.

Conti, F., Manzi, A. \& Pedrotti, F. - 1992- Libro rosso delle piante d'Italia — Ministero dell'Ambiente. WWF Italia. Soc. Bot. Italiana. Roma.

Conti, F., Manzi, A. \& Pedrotti, F. —1997— Liste rosse regionali delle piante d'Italia - WWF Italia (Eds.) Roma

Deil, U. - 1998 - The class Adiantetea in the Mediterranean area. A state of knowledge report - Ann. Bot. 56(1): 763-78.

Farris, E., Secchi, Z. \& Filigheddu, R. -2007- Caratterizzazione fitosociologica dell' habitat prioritario $6220 *_{\text {- }}$ "Percorsi substeppici di graminacee e piante annue dei Thero-Brachypodietea": caso di studio della Sardegna settentrionale - Fitosociologia 44(2) suppl. 1: 271-278.
Fiori, A. —1925-1929 — Nuova flora analitica d'Italia Firenze.

Foggi, B., Lastrucci, L., Papini, P., Vergari, S., Gennai, M., Gervasoni, D., Viciani, D. \& Ferretti, G. -2011- La vegetación del valle del rio Verdiana, Apeninos septentrionales (Pistoia-Italia Central) — Lazaroa 32: 153-178.

Franquesa, T. - 1995- El paisatge vegetal de la Península del Cap de Creus - Arx. Secc. Ci. Inst. Estud. Catalans 109: 1-628.

Galán de Mera, A., Morales Alonso, R. \& Vicente Orellana, J.A. - 2000- Pasture communities linked to ovine stock. A synthesis of the Poetea bulbosae class in the western Mediterranean Region - Phytocoenologia 30: 223-268.

Gianguzzi L., D'Amico, A. \& Romano, S. - 2010- Phytosociological remarks on residual woodlands of Laurus nobilis in Sicily — Lazaroa 31: 67-84

Gianguzzi, L. \& La Mantia, A. - 2008 - Contributo alla conoscenza della vegetazione e del paesaggio vegetale della Riserva Naturale "Monte Cofano" (Sicilia occidentale) - Fitosociologia, 45 (1) suppl. 1: 3-55.

Ladero, M., Biondi, E., Mossa, L. \& Amor, A. —1992Los pastizales mediterráneos presididos por Trifolium subterraneum L. en la isla de Cerdeña (Italia) - Doc. Phytosoc. 14: 45-64

Lentini, F., Di Geronimo, I., Grasso, M., Carbone, S., Sciuto, F., Scamarda, G., Cugno, G., Iozzia, S. \& Romeo, M. —1984 - Carta Geologica della Sicilia sudorientale. Scala 1: 100.000 - S.E.L.C.A., Firenze.

Lentini, F., Catalano, S. \& Carbone, S. - 2000- Carta Geologica della Provincia di Messina. Scala 1:50.000 S.E.L.C.A. Firenze.

Minissale, P. —1995- Studio fitosociologico delle praterie ad Ampelodesmos mauritanicus della Sicilia - Coll. Phytosoc. 21: 615-652.

Minissale, P., Sciandrello, S. \& Spampinato, G. —2005Analisi della biodiversità vegetale e relativa cartografia della Riserva Naturale Orientata Isola Bella e del territorio circostante (Taormina - ME - Sicilia) - Quad. Bot. Amb. Appl. 16: 175-208.

Minissale, P., Sciandrello, S. \& Spampinato, G. —2007Analisi della biodiversità vegetale e relativa cartografia della Riserva Naturale Orientata "Pantalica, Valle de1l'Anapo e Torrente Cava Grande " (Sicilia sudorientale) — Quad. Bot. Amb. Appl. 18: 241-303.

Minissale, P, Santo, A. \& Sciandrello, S. -2011- Analisi geobotanica del SIC "Capo Murro di Porco, Penisola della Maddalena e Grotta Pellegrino" (Siracusa, Sicilia) - Fitosociologia 48: 77-98.

Minissale, P. \& Sciandrello S. -2013- A relic wood of Juniperus turbinata Guss. (Cupressaceae) in Sicily. Ecological features and conservation perspectives - Plant Biosystems 147 (1): 145-157.

Pavone, P., Spampinato, G., Tomaselli V., Minissale P., Costa R., Sciandrello S. \& Ronsisvalle F. -2007Cartografia degli habitat della direttiva CEE 92/43 nei biotopi della Provincia di Siracusa (Sicilia orientale) Fitosociologia, 44(2) suppl. 1: 183-193. 
Pérez Prieto, D. \& Font, X. —-2005- Revisión sintaxonómica a nivel de subalianza del orden Helianthemetalia guttati en la Península Ibérica e Islas Baleares - Acta Bot. Malacitana 30: 139-156.

Podani, J. - 2001 - Sintax 2000 computer program for data analysis in ecology and systematics. Budapest

Nicotra, L. - 1878 - Prodromus florae messanensis Messina.

Raimondo, F. M., Gianguzzi, L. \& Ilardi, V. —1992- Inventario delle specie "a rischio" nella flora vascolare nativa della Sicilia — Quad. Bot. Amb. Appl. 3: 65-132.

Raimondo, F. M. \& Ilardi, V. —2009- Indagini fitosociologiche sulla vegetazione a Bupleurum fruticosum (Umbelliferae) del versante tirrenico della sicilia orientale Nat. Sicil. 33(4): 361-372.

Pignatti, S. -1982- Flora d'Italia. 1-3. Edagricole, Bologna.

Raimondo, F.M. \& Spadaro, V. —2009—Addenda et emendanda to the "A catalogue of plants growing in Sicily" — Flora Medit. 19: 303-312.

Ribeiro, S., Gonçalves, P. \& Espírito-Santo, M.D. —2012Land-use influence on Mediterranean perennial swards of Poa bulbosa: a case study in the International Tagus Region - Lazaroa 33: 51-64.

Rivas-Martinez, S. -1983- Pisos bioclimáticos de España — Lazaroa 5: 33-43.

Rivas-Martínez, S. - 1993 - Bases para una nueva clasificacion bioclimatica de la Tierra — Folia Bot. Matritensis 10: 1-23.

Rivas-Martínez, S. -2005- Notions on dynamic-catenal phytosociology as a basis of landscape science - Plant Biosyst. 139 (2): 135-144.

Rivas-Martínez, S. -2008- Globalbioclimatics. http:// www.globalbioclimatics.org.

Received: 21 February 2013

Accepted: 23 May 2013
Rivas-Martínez, S., Penas A. \& Díaz T.E. -2004- Biogeographic map of Europe. Cartographic service, University of León.

Rivas-Martínez, S., Fernández González, F., Loidi, J., Lousa, M. \& Penas, A. —2001- Syntaxonomical ChekList of vascular plant communities of Spain and Portugal to association level - Itinera Geobot. 14: 5-341.

Sciandrello, S., Brullo, C., Brullo, S., Giusso del Galdo, G., Minissale, P. \& Salmeri C. - 2013- A new species of Brassica sect. Brassica (Brassicaceae) from Sicily Plant Biosystems 147(3): 812-820.

Sciandrello, S. \& D'Agostino S. —2013- Distribution patterns and floristic analysis of the Colymbada tauromenitana (Guss.) Holub populations in Sicily (Italy) Acta Bot. Croatica (in press).

Silva, V., Pinto-Cruz, C. \& Espirito-Santo, M.D. - 2009Temporary ponds and hygrophilous grasslands plant communities in the Monfurado Site of Community Importance - Lazaroa 30: 81-88.

Tomaselli, V., Tenerelli, P. \& Sciandrello, S. -2012Mapping and quantifying habitat fragmentation in small coastal areas: a case study of three protected wetlands in Apulia (Italy) — Environ. Monit. Assess. 184: 693713.

Tutin, T.G. \& al. (Eds.) -1964-1993 - Flora Europaea, vols. 1-5 - Cambridge Univ. Press, Cambridge.

Van der Maarel, E. —1979- Trasformation of cover abundance values in phytosociology and its effects on community similarity - Vegetatio 39: 97-144.

Zampino, S., Duro, A., Piccione, V. \& Scalia C. —1997Fitoclima della Sicilia. Termoudogrammi secondo Walter \& Lieth - Atti $5^{\circ}$ Workshop Prog. Strat. C.N.R. "Clima, Ambiente e Territorio nel Mezzogiorno"Amalfi 2: 7-54. 